\title{
In Defense of the Short Cut
}

\author{
Stephen M. Johnson ${ }^{*}$
}

\section{INTRODUCTION}

Congress frequently gives administrative agencies a choice of several different tools-including legislative rulemaking, nonlegislative rulemaking, and adjudication - to interpret and apply the statutes that they administer. ${ }^{1}$ When Congress gives agencies a choice, courts rarely second-guess the agencies' choice of policymaking tool. ${ }^{2}$ Rarely, that is, unless the agency chooses to interpret a statute through nonlegislative rulemaking.

In theory, an agency should be able to announce an interpretation of a statute through a policy statement, interpretive rule, or other form of nonlegislative rule-often referred to more generally as "guidance documents"-without incurring the costs or delay of notice-andcomment rulemaking. ${ }^{3}$ As long as the agency does not treat that policy decision as binding and justifies the decision when applying it to a concrete factual situation, there should be nothing legally objectionable about the agency's action. ${ }^{4}$

Nevertheless, regulated entities and regulatory beneficiaries frequently challenge nonlegislative rules before the agency applies them, arguing that the policy decisions are really legislative rules and thus invalid because they were adopted without notice-and-comment procedures. ${ }^{5}$ In response, courts have fashioned a variety of unworkable

\footnotetext{
* Associate Dean and Professor, Walter F. George School of Law, Mercer University; B.S., J.D., Villanova University; LL.M., George Washington University School of Law.

1. See infra notes 31-36 and accompanying text.

2. See infra notes $72-81$ and accompanying text.

3. See Stephen M. Johnson, Good Guidance, Good Grief!, 72 Mo. L. REV. 695, 698-702 (2007) (discussing nonlegislative rulemaking and the reasons underlying its use).

4. Id. at 707-08.

5. See, e.g., David L. Franklin, Legislative Rules, Nonlegislative Rules, and the Perils of the Short Cut, 120 YALE L.J. 276, 294-303 (2010) (discussing various challenges to rules promulgated without notice-and-comment procedures); William Funk, When Is a "Rule" a Regulation? Marking a Clear Line Between Nonlegislative Rules and Legislative Rules, 54 ADMIN. L. REv. 659, 660-61 (2002) (same); M. Elizabeth Magill, Agency Choice of Policymaking Form, 71 U. CHI. L. ReV.
} 
tests to distinguish between legislative and nonlegislative rules, and they have frequently struck down nonlegislative rules by characterizing them as invalid legislative rules that the agency should have promulgated through notice-and-comment procedures. ${ }^{6}$

Many academics have criticized these tests and suggested that a court, in reviewing an agency's policy decision, should simply look at the procedures that the agency used to make the decision. ${ }^{7}$ If the agency did not use notice-and-comment rulemaking, the reformers argue, then the court should conclude that the agency's policy decision is a nonlegislative rule instead of concluding that it is an invalid legislative rule. $^{8}$ The agency may then apply that nonlegislative rule to concrete factual situations, but it must independently and rationally justify its decision in those cases and cannot simply point to the nonlegislative rule as a source of binding authority. ${ }^{9}$

This proposal has generated much scholarly debate. Critics argue that the proposal reduces public input in the decision-making process and reduces judicial oversight because agencies' nonlegislative rules are frequently not reviewable in court. ${ }^{10}$ Supporters of the proposal counter by claiming that it does not eliminate public or judicial oversight of nonlegislative rules but merely delays review until the agencies apply the policy decisions in a concrete factual setting. ${ }^{11}$ Further, supporters argue that agencies will frequently articulate their most significant policy decisions in legislative rules adopted through notice-and-comment rulemaking because such rules will be binding and entitled greater deference upon review. ${ }^{12}$

The debate has continued in recent articles by Professors David Franklin and Mark Seidenfeld. ${ }^{13}$ Franklin argues that courts have

1383, 1411-12 (2004) (discussing such challenges generally); see also Andrew Childers, EPA Guidance on Polluter Fees Violates Clean Air Act, NRDC Tells Appeals Court, 42 Env't Rep. (BNA) 1032 (May 13, 2011); Linda Roeder, 170 House Members Call EPA Guidance on Water Act Jurisdiction “De Facto Rule”, 42 Env’t Rep. (BNA) 872 (Apr. 22, 2011).

6. See infra notes 103-04 and accompanying text.

7. See, e.g., Funk, supra note 5, at 663; Jacob E. Gersen, Legislative Rules Revisited, 74 U. CHI. L. REV. 1705, 1719 (2007); John F. Manning, Nonlegislative Rules, 72 GeO. WASH. L. REV. 893, 931 (2004).

8. See sources cited supra note 7 .

9. See, e.g., E. Donald Elliott, Re-Inventing Rulemaking, 41 DuKE L.J. 1490, 1490-91 (1992); Funk, supra note 5, at 664, 671; Johnson, supra note 3, at 707-08.

10. See infra notes $155-67$ and accompanying text.

11. See infra notes $168-74$ and accompanying text.

12. See infra notes $168-74$ and accompanying text.

13. See Franklin, supra note 5; Mark Seidenfeld, Substituting Substantive for Procedural Review of Guidance Documents, 90 TEX. L. REV. 331 (2011). 
appropriately rejected the proposal—which he deems the "short cut"because there are many situations where agencies' nonlegislative rules will be unreviewable yet will directly and concretely impact regulated entities and regulatory beneficiaries. ${ }^{14}$ He also asserts that agencies will not use notice-and-comment rulemaking for major policy decisions, as supporters of the short cut assert, because courts will accord agencies' decisions made through nonlegislative rulemaking or adjudication a similar amount of deference as decisions made through legislative rulemaking. ${ }^{15}$ Finally, he argues that even if there is some opportunity for public participation in policymaking when a party challenges an agency's application of a nonlegislative rule, the nature and level of this public participation differs significantly from the participation in legislative rulemaking. ${ }^{16}$

Seidenfeld, on the other hand, defends the short cut but concedes that it does reduce public and judicial oversight of agency policymaking. ${ }^{17}$ Accordingly, he proposes modifications of the standard of review for nonlegislative rules and the doctrines of ripeness and finality. ${ }^{18}$ Such modifications would allow nonlegislative rules to be challenged immediately upon adoption and require that courts apply a more rigorous standard of review. ${ }^{19}$

Seidenfeld's proposal, however, could provide a disincentive to agencies' use of nonlegislative rulemaking, encouraging adjudication rather than legislative rulemaking. ${ }^{20}$ A shift to adjudication would not significantly increase public participation in agency decision-making and would reduce advance notice to regulated entities and regulatory beneficiaries regarding agencies' interpretations of the laws they administer. $^{21}$

Seidenfeld and earlier advocates of the short cut are correct that the test is much easier to apply than current tests and more faithful to basic principles of administrative law. ${ }^{22}$ In addition, the short cut is more consistent with congressional intent regarding agencies' choice of

\footnotetext{
14. See Franklin, supra note 5, at 308-12.

15. Id. at 312-16, 320-23.

16. Id. at 317-19.

17. See Seidenfeld, supra note 13 , at 341-44.

18. Id. at 373-75.

19. Id. at $375-78$.

20. See infra Part V.D.

21. See infra Part V.D.

22. See infra notes 200-09 and accompanying text.
} 
policymaking form. ${ }^{23}$ If Congress has given an agency discretion to interpret a statute through legislative rulemaking, nonlegislative rulemaking, or adjudication, then courts should honor that directive. ${ }^{24}$

Franklin and Seidenfeld are correct, however, that in some cases the short cut may reduce public and judicial oversight over agency policymaking. ${ }^{25}$ Reforms to address those limitations should increase public and judicial oversight without significantly increasing the cost to the agency of making decisions through nonlegislative rules. Regarding judicial oversight, this Article proposes an expansion of judicial review for nonlegislative rules in cases where an agency is unlikely to apply a nonlegislative rule to a concrete factual situation. Such cases exist when an agency decides to deregulate or not enforce the law or regulations in specific instances. ${ }^{26}$ This approach addresses the concerns about limited judicial review under the short cut in a manner that is consistent with the true nature of nonlegislative rules; it achieves this, however, without greatly expanding the circumstances in which a claimant may bring a lawsuit.

Regarding public participation, this Article advocates amendment of the Administrative Procedure Act (APA) to require an agency to post significant guidance documents on the Internet, allow an opportunity for public comment on those documents, and post the comments on the Internet, without requiring the agency to prepare a "concise general statement of the basis and purpose" of the guidance or respond to the comments. ${ }^{27}$ Although I opposed an increase in procedures for guidance documents in an earlier article, ${ }^{28}$ agencies have adhered to these procedures for several years, at the direction of the White House Office of Management and Budget (OMB), ${ }^{29}$ without a legislative mandate; the procedures have not appeared to cause any significant shift away from nonlegislative rulemaking. The proposal would only apply to significant guidance documents, so the impact would be minimal and targeted at

\footnotetext{
23. See infra notes $251-53$ and accompanying text.

24. See infra notes 251-53 and accompanying text.

25. See Franklin, supra note 5, at 324; Seidenfeld, supra note 13, at 332-33; infra notes 195-96 and accompanying text.

26. See infra Part V.G.2.

27. See infra Part V.G.1.

28. See Johnson, supra note 3, at 696-97 (stating that agencies would be better served with general requirements when adopting procedures for notice-and-comment rulemaking).

29. See Final Bulletin for Agency Good Guidance Practices, 72 Fed. Reg. 3432, 3432-33 (Jan. 25,2007 ) (discussing agencies' reliance on guidance documents and their general importance to agencies).
} 
those nonlegislative rules that are likely to raise the greatest concerns among regulated entities and regulatory beneficiaries. The proposal is also consistent with the current Administration's focus on e-rulemaking and increasing participation and transparency in government. ${ }^{30}$

It might even be appropriate, as part of the legislation to expand judicial review and public participation, to require agencies to notify Congress when they adopt significant guidance documents. Because the guidance documents and public comments would be accessible on the Internet, members of Congress could review them and determine whether it was necessary to require agencies to make specific decisions or types of decisions through legislative rulemaking.

Part II of this Article explores the variety of policymaking tools that are available to agencies, the deference generally accorded an agency's choice of tool, and the reluctance of courts to defer when agencies choose to make policy through nonlegislative rulemaking. Part III explores Franklin's criticism of the short cut as an alternative to the current tests used to distinguish legislative rules from nonlegislative rules. Part IV outlines Seidenfeld's proposal to reform judicial review of nonlegislative rules to allow courts to adopt the short cut without limiting public and judicial oversight. Finally, Part V critiques the proposals of Franklin and Seidenfeld and introduces the proposal for an expansion of electronic participation in the development of significant guidance documents and a modest expansion of judicial review for nonlegislative rules.

\section{Legislative Rules, Nonlegislative Rules, AdJudication, AND AGENCY CHOICE}

\section{A. Agency Policymaking Tools and Agency Choice}

Congress frequently authorizes administrative agencies to interpret and apply the statutes that they administer through a variety of tools, including legislative rulemaking, adjudication, and nonlegislative rulemaking. ${ }^{31}$ The precise mix of tools available to an agency depends upon the statutes that empower the agency to regulate. ${ }^{32}$ To implement

30. See infra notes 323-24 and accompanying text.

31. See Magill, supra note 5, at 1386.

32. Id. at 1387. Although Congress normally must use explicit language to grant legislative rulemaking authority, enforcement authority, or other adjudicatory authority, the Supreme Court has held that a statute that authorizes an agency to gather information and judicially enforce the statute 
the Clean Water Act, for example, Congress authorized the Environmental Protection Agency (EPA) to use the full range of policymaking tools. ${ }^{33}$ By contrast, when Congress authorized the Equal Employment Opportunity Commission (EEOC) to implement Title VII of the Civil Rights Act, it did not authorize the EEOC to promulgate legislative rules. ${ }^{34}$ Just as Congress may limit an agency's choice of policymaking tools by withholding the power to use a specific tool, as in the EEOC example, Congress may limit the agency's choice by requiring the agency to use a specific tool. For instance, Congress required the EPA to use legislative rulemaking to set certain waterquality standards under the Clean Water $\mathrm{Act}^{35}$ and to establish methods for identifying and listing hazardous wastes under the Resource Conservation and Recovery Act. ${ }^{36}$

If an agency has a choice regarding the tools that it may use to interpret and implement the statute it administers, several factors might influence the agency's choice in a particular situation. These include the procedures required, the audiences involved in the decision-making, the effect of the decision, and the amount of deference accorded by courts to the agency's decision.

First, there are different procedural requirements for each tool. In order to adopt a legislative rule, an agency must publish the proposed rule in the Federal Register, provide the public with an opportunity to comment on the proposed rule, and publish the final rule with a concise general statement of the basis and purpose for the rule. ${ }^{37}$ In many cases, the OMB must review the rule prior to publication. ${ }^{38}$ If, on the other hand, an agency chooses to interpret a statute or regulation on a case-bycase basis through adjudication, the agency may have to follow trial-type procedures if the agency's statutory authority requires formal

also grants the authority to issue rules interpreting the statute regardless of whether the statute explicitly grants such authority. Skidmore v. Swift \& Co., 323 U.S. 134, 139-40 (1944).

33. 33 U.S.C. $\S \S 1319(b), 1361$ (a) (2006) (authorizing EPA Administrator to bring judicial enforcement actions and promulgate legislative rules); 33 U.S.C. §1319(g) (authorizing administrative enforcement actions).

34. 42 U.S.C. § 2000e-12(a) (2006) (authorizing only procedural regulations).

35. See 33 U.S.C. § 1316.

36. See 42 U.S.C. § 6921(b) (2006).

37. 5 U.S.C. § 553 (2006). In rare situations, Congress may require an agency to promulgate a rule through a formal rulemaking process, which involves trial-type proceedings. See 5 U.S.C. $\S 553$ (c) (applying $\S \S 556$ and 557 when a statute requires rulemaking on the record rather than in the Federal Register); see also 5 U.S.C. $§ 554$ (establishing procedures for adjudication hearings when rulemaking must be made on the record).

38. Exec. Order No. 12,866, 58 Fed. Reg. 51,735 (Sept. 30, 1993). 
adjudication. ${ }^{39}$ The OMB will not, however, participate in that process. ${ }^{40}$ If the statute merely requires informal adjudication, then few mandatory procedures apply, and there will be no OMB involvement. ${ }^{41}$ The final tool, nonlegislative rulemaking, which includes general statements of policy and interpretive rules, is exempt from the notice-and-comment process and most other procedures. ${ }^{42}$ OMB reviews only a small category of these rules. ${ }^{43}$

Just as the procedures an agency must follow vary greatly depending on the agency's choice of policymaking tool, the audiences that participate in an agency's decision-making also vary significantly. Legislative rulemaking affords the broadest opportunity for public participation because the agency provides nationwide notice of the proposed rule, which allows any interested person to submit comments on the rules. ${ }^{44}$ The audience involved in an agency's decision-making is more limited with formal adjudication and usually only includes the parties to the agency action and persons that can meet the requirements to intervene in the proceedings. ${ }^{45}$ If an agency makes a decision through informal adjudication, then even fewer persons are likely to be involved since fewer people are likely to be aware that the agency is engaged in the adjudication. ${ }^{46}$ Finally, with many nonlegislative rules, the only people outside the agency who will be involved in the decision-making process will be those contacted by the agency. ${ }^{47}$

39. See 5 U.S.C. $\S 556$.

40. See 1 Kenneth Culp Davis \& Richard J. Pierce, JR., Administrative law Treatise $\S 7.9$ (4th ed. 2002) (noting that executive influence over adjudication proceeding implicates Due Process Clause concerns).

41. See 5 U.S.C. $\S 555(\mathrm{e})$. Informal adjudication requires that the agency simply provide prompt notice and a brief statement of the grounds for denial whenever the agency denies a "written application, petition, or other request of an interested person made in connection with any agency proceeding." Id.

42. Id. §553(b); see also Johnson, supra note 3, at 699; Nina A. Mendelson, Regulatory Beneficiaries and Informal Agency Policymaking, 92 CoRnell L. Rev. 397, 406 (2007). Agencies must publish and make available some, but not all, nonlegislative rules. 5 U.S.C. § 552(a).

43. See Exec. Order No. 12,866, 58 Fed. Reg. 51,735 (Sept. 30, 1993) (providing that review is not required for rules issued under formal rulemaking provisions, rules that pertain to military and foreign affairs, and rules that are limited to agency organization, management, or personnel matters); see also Magill, supra note 5, at 1393 (noting that although "[i]ndependent agencies participate in the government-wide planning process, [they] are not required to submit their significant regulatory actions for review and approval”).

44. 5 U.S.C. § 553.

45. Magill, supra note 5, at 1391; Seidenfeld, supra note 13, at 337-38.

46. See Seidenfeld, supra note 13, at 339.

47. See Mendelson, supra note 42, at 425 (noting some agencies' practice of soliciting comment but stating that they are generally not required to do so). 
The legal effect of the various tools can greatly influence an agency's choice of policymaking tool. Legislative rules have the force and effect of law. ${ }^{48}$ When an agency enforces a legislative rule on a case-by-case basis, it does not have to independently justify the basis for the rule. ${ }^{49}$ Adjudication technically binds only the parties to the proceeding, ${ }^{50}$ but the order may set a precedent that encourages similarly situated persons to comply with the order in the future. ${ }^{51}$ Finally, nonlegislative rules do not bind the agency, the regulated community, or the public. $^{52}$ They do not have any independent legal force. If an agency applies the policy articulated in a nonlegislative rule on a case-by-case basis in adjudication, then the agency must justify the rationale behind the policy as applied to the facts of the case in a rational manner. ${ }^{53}$ The agency cannot simply rely on the rule as if it were a legislative rule. ${ }^{54}$ The agency must support the policy as if the nonlegislative rule had never been issued. ${ }^{55}$ Although nonlegislative rules are not legally binding, they may be binding as a practical matter for entities that are unwilling to (1) incur the cost or potential harm to the relationship with an agency by challenging rules before they are enforced or (2) run the risk of paying penalties and suffering negative public perception if they wait and mount an unsuccessful challenge to the rules when they are enforced. $^{56}$

The final important difference between the various policymaking tools available to agencies is the degree of deference that courts accord to decisions made using those tools. When an agency interprets a statute

48. See Magill, supra note 5, at 1394 (proffering that a valid legislative rule operates like a statute).

49. See 1 DAVIS \& PIERCE, supra note 40, § 6.4.

50. Magill, supra note 5, at 1394.

51. Id.

52. See id.; Mendelson, supra note 42, at 400-01, 406-07. Professor Elizabeth Magill notes, however, that like a policy adopted through adjudication, a policy articulated in a nonlegislative rule and upheld in an adjudication may set a precedent that encourages future compliance by similarly situated persons. Magill, supra note 5, at 1394. Professor John Manning has argued that one type of nonlegislative rule-interpretative rules—can be binding. See Manning, supra note 7, at 920-23. It is the statute or regulation interpreted by the rule, rather than the interpretative rule, that is binding.

53. See Mendelson, supra note 42, at 407, 412.

54. Id.

55. See Manning, supra note 7, at 931. The agency "must be able to justify its decision by reference to norms found elsewhere-either in the statute, an antecedent legislative rule, or adjudicative precedents interpreting those sources of authority.” Id. (citing Pac. Gas \& Elec. Co. v. Fed. Power Comm'n, 506 F.2d 33, 38 (D.C. Cir. 1974)).

56. Mendelson, supra note 42, at 400, 407 (stating that agency "guidance documents often have rule-like effects on regulated entities”); see also infra notes 150, 182 and accompanying text. 
through a legislative rule, courts review the agency's interpretation under a deferential standard established by the Supreme Court in Chevron U.S.A. Inc. v. Natural Resources Defense Council, Inc. ${ }^{57}$ The Chevron test requires that a court first ask "whether Congress has directly spoken to the precise question at issue." 58 If Congress clearly expressed its intent, then both the agency and the court are bound by it. ${ }^{59}$ Conversely, if a court determines that Congress has been silent or ambiguous regarding the proper interpretation of a statute, then the court must ask "whether the agency's answer is based on a permissible construction of the statute." ${ }^{\circ 0}$ The Chevron test likely also applies to decisions that agencies make through formal adjudication. In United States v. Mead Corp., the Supreme Court held that Chevron applies "when it appears that Congress delegated authority to the agency generally to make rules carrying the force of law, and that the agency interpretation claiming deference was promulgated in the exercise of that authority."61 According to the Court, a "[d]elegation of such authority may be shown in a variety of ways, as by an agency's power to engage in adjudication or notice-and-comment rulemaking, or by some other indication of comparable congressional intent.", 62

Although the Mead Court left open the possibility that Chevron deference might apply to nonlegislative rules, ${ }^{63}$ and although the Court suggested in Barnhart v. Walton that nonlegislative rules might qualify for Chevron deference in some cases, ${ }^{64}$ most lower courts have not accorded such deference to nonlegislative rules in practice. ${ }^{65}$ Instead, most courts accord nonlegislative rules a lesser degree of deference based on a variety of factors laid out by the Supreme Court in Skidmore $v$. Swift \& Co. ${ }^{66}$ The Court held that the level of deference accorded an

57. See 467 U.S. 837, 842-44 (1984). "[T]he court does not simply impose its own construction on the statute, as would be necessary in the absence of an administrative interpretation." Id. (footnote omitted) (citing Roscoe Pound, THE SPIRIT OF THE COMMON LAW 174-75 (1921)).

58. Id. at 842 .

59. Id. at $842-43$.

60. Id. at 843 .

61. 533 U.S. $218,226-27$ (2001).

62. Id. at 227.

63. Id. at 227-28.

64. 535 U.S. 212, 222 (2002) ("Mead pointed to instances in which the Court has applied Chevron deference to agency interpretations that did not emerge out of notice-and-comment rulemaking.” (citing Mead, 533 U.S. at 230-31)).

65. See Funk, supra note 5, at 663 ("[C]ourts have traditionally bemoaned the difficulty of determining whether a given rule is a legislative rule, an interpretive rule, or a statement of policy.").

66. 323 U.S. 134, 140 (1944). 
agency's interpretation of a statute depends on "the thoroughness evident in its consideration, the validity of its reasoning, its consistency with earlier and later pronouncements, and all those factors which give it power to persuade, if lacking power to control., ${ }^{\circ 7}$

An agency's choice of policymaking tool may depend on many other factors as well, including "how sure the agency is about what policy it wishes to adopt, how frequently the agency anticipates the question will come up, whether the issue is inherently entangled with other issues that can best be addressed comprehensively, and what other issues are currently pressing for the agency's attention.”,68

An agency's choice of policymaking tool has important repercussions for regulated entities as well as regulatory beneficiaries who participate in the agency's regulatory scheme. For instance, regulated entities may think that it is unfair for an agency to announce a new policy in an adjudication because the agency can impose the new policy retroactively on the target without advance notice and without soliciting broad input on development of the policy. ${ }^{69}$ Regulatory beneficiaries might also criticize the lack of public participation and could complain that the agencies' decision would have a limited precedential effect. $^{70}$ If an agency decides to announce a new policy through legislative rulemaking, on the other hand, then regulatory beneficiaries might criticize the delay involved in developing the policy in that manner, and regulated entities might prefer that the agency develop the policy incrementally through adjudication and retain more flexibility in responding to different factual scenarios. ${ }^{71}$

While an agency's choice of policymaking tool may be criticized by regulated entities and regulatory beneficiaries, courts rarely overturn an agency's choice, although they may overturn the policy adopted by the agency using that tool. Significantly, courts generally do not even require agencies to provide an explanation for their choice of rulemaking

67. Id.

68. Elliott, supra note 9, at 1492.

69. See Magill, supra note 5, at 1396 (describing the consequences of a lack of public input).

70. See id

71. See id. at 1396-97. 
or adjudication. ${ }^{72}$ As Professor Elizabeth Magill notes, the judicial reaction to an agency's choice of policymaking tool

can be simply described: hands-off. . . . This judicial reaction is out of step with the rest of the law of judicial review of agency action. Courts usually demand that agencies provide reasoned explanations for their discretionary choices, but there is no such reason-giving requirement when agencies select their preferred policymaking form. ${ }^{7}$

The Supreme Court adopted this deferential approach decades ago in SEC v. Chenery Corp. (Chenery II). ${ }^{74}$ In discussing the SEC's decision to interpret a statute through case-by-case adjudication instead of rulemaking, the Court indicated that an agency should rely on prospective rules wherever possible, "[b]ut any rigid requirement to that effect would make the administrative process inflexible and incapable of dealing with many of the specialized problems which arise." ${ }^{\text {,5 }}$ The Court suggested that there were many situations where an agency should have the ability to develop policy on a case-by-case basis, including situations where unexpected problems arise, where the agency does not have sufficient experience to generate a general rule, or where the problem addressed was so specialized or varying that a general approach is not justified. ${ }^{76}$ Nevertheless, the Court ultimately held that "the choice made between proceeding by general rule or by individual, ad hoc litigation is one that lies primarily in the informed discretion of the administrative agency."77 Even though the Chenery II Court suggested that adjudication might be a better approach for policymaking in certain circumstances, subsequent cases have not required agencies to use adjudication or imposed other limits on agencies' discretion in choosing an appropriate policymaking tool. ${ }^{78}$

72. Id. at 1385. Professor Magill notes, however, that there are exceptions that limit an agency's discretion. As she stresses, Congress may require an agency to use a specific tool to make a decision, an agency may limit its discretion in advance by announcing that it will use a specific tool to make certain types of decisions, or constitutional due process requirements may require an agency to use a specific tool. Id. at 1409-10.

73. Id. at 1385. Professor Magill notes that an agency can make that choice "for a good reason, a bad reason, or no detectable reason.” Id. at 1415.

74. 332 U.S. 194 (1947).

75. Id. at 202 .

76. Id. at 202-03.

77. Id. at 203 (citing CBS v. United States, 316 U.S. 407, 421 (1942)).

78. Magill, supra note 5, at 1408 (citing NLRB v. Bell Aerospace Co., 416 U.S. 267, 292-94 (1974)). 
In NLRB v. Bell Aerospace Co., the Court recognized that an agency's choice can be reviewed for "abuse of discretion,"79 but lower courts have been reluctant to do so. ${ }^{80}$ In fact, courts have generally only overturned an agency's choice when the agency used adjudication to overturn a prior rule and the retroactive application of the new policy would cause significant hardship. ${ }^{81}$

\section{B. Nonlegislative Rules}

While courts uniformly apply the Chenery II approach when an agency chooses adjudication over rulemaking and vice versa, courts have been more willing to interfere when an agency decides to implement a policy through nonlegislative, rather than legislative, rulemaking. ${ }^{82}$ Nonlegislative rules_-sometimes referred to more generally as guidance documents-include "general statements of policy and interpretive rules." ${ }^{83}$ General statements of policy describe "how an agency intends to exercise discretion that it is given to implement the statutes and regulations it administers, ${ }^{84}$ while interpretive rules explain an agency’s

\section{416 U.S. at 294 .}

80. See Magill, supra note 5, at 1408 (citing the limited circumstances when lower courts have “invalidated an agency's reliance on adjudication instead of rulemaking”).

81. Id.

82. As noted below, courts do not ignore Chenery II in this context and invalidate an agency's choice of nonlegislative rulemaking over legislative rulemaking, and they do not require agencies to explain their choice of nonlegislative rulemaking. Instead, courts find that nonlegislative rules adopted by agencies are, in fact, legislative rules, and courts invalidate the rules on the ground that the agency failed to use the procedures required for legislative rulemaking. See Magill, supra note 5, at 1441 (noting courts' concern with inappropriate reliance on guidance documents); see also infra notes 103, 113-19 and accompanying text.

83. Mendelson, supra note 42, at 398 (citing 5 U.S.C. §553(b)(3)(A) (2006)). Guidance documents issued by agencies vary greatly in the level of formality and can include manuals for agency staff, letter rulings, advice provided in phone conversations, circulars, and press releases. See William Funk, A Primer on Nonlegislative Rules, 53 ADMIN. L. REV. 1321, 1322-23 (2001) (providing examples of agency pronouncements); Magill, supra note 5, at 1391 (citing the wide range of agency instruments considered guidance documents); Manning, supra note 7, at 893 (listing types of informal policymaking issuances) (citing Richard J. Pierce, Rulemaking and the Administrative Procedure Act, 32 TULSA L.J. 185, 185 (1996)). There is some debate about whether there is, or should be, a distinction between interpretive rules and general statements of policy, but courts have occasionally distinguished between them and developed different tests for distinguishing each from legislative rules. See Funk, supra, at 1324 (noting that not all commentators agree that there is a distinction between these types of rules but that the courts have distinguished them). General statements of policy and interpretive rules, like legislative rules, are "rules" under the APA, which defines a "rule" as "an agency statement of general or particular applicability and future effect designed to implement, interpret, or prescribe law or policy.” 5 U.S.C. § 551(4).

84. Seidenfeld, supra note 13 , at 346. 
interpretation of a statute or regulation. ${ }^{85}$ Over the last few decades, agencies have issued significantly more nonlegislative rules than legislative rules. ${ }^{86}$ For instance, the Food and Drug Administration issued about twice as many guidance documents as rules between 2001 and 2003; ${ }^{87}$ between 1996 and 1999, the EPA issued over two thousand guidance documents, compared to one hundred "significant" legislative rules. ${ }^{88}$

Many reasons underlie the trend toward nonlegislative rulemaking. General consensus indicates that the notice-and-comment rulemaking process has become ossified over the last few decades as Congress, ${ }^{89}$ courts, $^{90}$ and the executive branch $^{91}$ have imposed substantial new procedural requirements on the notice-and-comment process. $^{92}$ The process for adopting nonlegislative rules is quicker and less expensive than legislative rulemaking ${ }^{93}$ and frees agency resources to address other

85. See id.

86. See Magill, supra note 5, at 1385 (noting the shift that occurred as administrative agencies began pursuing mandates by promulgating legislative rules).

87. Erica Seiguer \& John J. Smith, Perception and Process at the Food and Drug Administration: Obligations and Trade-Offs in Rules and Guidances, 60 FOOD \& DRUG L.J. 17, 2526 (2005).

88. Mendelson, supra note 42, at 399.

89. See, e.g., 44 U.S.C. § 3507 (2006) (requiring submission of information-collection requests for certain rules under the Paperwork Reduction Act of 1995); 2 U.S.C. § 1532(a) (2006) (requiring analyses of alternatives for certain rules under the Unfunded Mandates Reform Act of 1995); 5 U.S.C. § 603 (2006) (requiring an initial flexibility analysis for certain rules under the Regulatory Flexibility Act).

90. Under the current interpretation of the APA provision that requires an agency to provide "a concise general statement of the basis and purpose” of its final rule, 5 U.S.C. § 553(c), the agency must address and rationally respond to the public comments relating to the proposed rule. See Lloyd Noland Hosp. \& Clinic v. Heckler, 762 F.2d 1561, 1566-67 (11th Cir. 1985) (noting that the general statement "should fully explain the factual and legal basis for the rule" (citing S. REP. NO. 752, at 14 (1946))); United States v. N.S. Food Prods. Corp., 568 F.2d 240, 252-53 (2d Cir. 1977) (requiring agencies to respond to "vital questions" raised by comments). As a result, before an agency issues a final rule, it typically invests substantial time and resources to identify and formulate cogent responses to public comments.

91. See, e.g., Exec. Order No. 13,563, 76 Fed. Reg. 3821, 3822 (Jan. 18, 2011) (improving regulation and regulatory review and requiring agencies to seek the views of those who are likely to be affected); Exec. Order No. 13,132, 64 Fed. Reg. 43,255, 43,256 (Aug. 4, 1999) (requiring federalism-impacts analysis when formulating and implementing policies); Exec. Order No. 12,630, 53 Fed. Reg. 8859, 8862 (Mar. 18, 1988) (requiring takings analyses for proposed regulatory actions).

92. Johnson, supra note 3 , at 700-01.

93. Seidenfeld, supra note 13, at 340-41; see also Johnson, supra note 3, at 701 ("[T] for adopting nonlegislative rules is significantly quicker and less expensive than the ... rulemaking process ... .”); Magill, supra note 5, at 1392 (“[G]uidance documents permit the agency to develop policy relatively cheaply.”); Mendelson, supra note 42, at 408 (“[I]ssuing a guidance is relatively cheap compared with the costs of notice-and-comment rulemaking.” (citing OFFICE OF MGMT. \& 
important priorities. ${ }^{94}$ In addition, nonlegislative rules provide agencies with the flexibility to change and refine their policies and interpretations more quickly. ${ }^{95}$ Nonlegislative rules are also subject to less presidential and congressional oversight than legislative rules. ${ }^{96}$

"While agencies could choose to make policies and interpretations through adjudication, adoption of nonlegislative rules, like the adoption of legislative rules, enables agencies to give advance notice to the regulated community and regulatory beneficiaries about the agencies' interpretations and policies."97 Since guidance documents apply prospectively, using them protects reliance interests better than adjudication. ${ }^{98}$ The use of nonlegislative rules "also enables agencies to promote consistent decisionmaking and application of the law by their employees." $" 99$

Although agencies that adopt policies through nonlegislative rulemaking sacrifice the binding nature, increased deference, ${ }^{100}$ transparency, ${ }^{101}$ and opportunity to obtain more information from a

Budget, EXec. OfFICE OF THE PRESIDENT, DRAFt 2005 REPORT to CONGRESS ON THE COSTS AND BENEFITS OF FEDERAL REgULATIONS 6 (2005))). Recent notice-and-comment rulemaking by the FCC, the EPA, and the Forest Service has spawned hundreds of thousands of comments. Cary Coglianese, Citizen Participation in Rulemaking: Past, Present, and Future, 55 DUKE L.J. 943, 954 (2006).

94. Franklin, supra note 5, at 304.

95. Johnson, supra note 3, at 701; see also Manning, supra note 7, at 914 (noting that nonlegislative documents are a "flexib[le]" option for agencies to change their policies); Mendelson, supra note 42, at 408-10 ("The agency also retains the ability to change the guidance inexpensively and quickly."); Seidenfeld, supra note 13, at 340 ("Notice-and-comment procedures are... an inefficient means of tweaking policy or interpretations already adopted by legislative rule.”).

96. Johnson, supra note 3, at 701-02; see also Mendelson, supra note 42, at 410 ("Guidance documents receive very limited review from Congress and the White House.”).

97. Johnson, supra note 3, at 702; see also Franklin, supra note 5, at 303-04 (stating that nonlegislative rules "provide[] relatively swift and accurate notice to the public of how the agency interprets the statutes or rules that it administers"); Funk, supra note 83, at 1332 (noting that these documents provide guidance as to the agencies' intentions to regulated entities); Manning, supra note 7, at 914-15 ("[N]onlegislative rules potentially allow agencies ... to give the public valuable notice of anticipated policies.”); Mendelson, supra note 42, at 402 (noting that these documents are better than the alternative of no notice of the agency's implementation or enforcement approaches).

98. Seidenfeld, supra note 13, at 341.

99. Johnson, supra note 3, at 702; see also Franklin, supra note 5, at 304 (“[N]onlegislative rulemaking allows agency heads to inform lower-level employees promptly about changes in agency policy.”); Manning, supra note 7, at 914-15 (“[N]onlegislative rules potentially allow agencies to supply often far-flung staffs with needed direction ....”); Mendelson, supra note 42, at 402 ("[T]he documents help agencies guide the conduct of lower-level employees.”).

100. Manning, supra note 7, at 937-40; see supra notes 48-62 and accompanying text.

101. The use of guidance documents to articulate policies and interpretations may impair the public's knowledge of and compliance with the law. Johnson, supra note 3, at 703. 
broader audience available through legislative rulemaking, ${ }^{102}$ the advantages of nonlegislative rulemaking outlined above frequently exceed those of legislative rulemaking.

\section{Distinguishing Legislative Rules From Nonlegislative Rules}

As agencies have adopted more policies and interpretations through nonlegislative rulemaking, regulated entities and regulatory beneficiaries have challenged those policy decisions, frequently before agencies have applied the policies to them. In most cases, the challengers argue that the agencies' policies are, in fact, legislative rules that the court should invalidate because the agencies did not use the notice-and-comment procedures as required for legislative rulemaking. ${ }^{103}$ Increasingly, courts, led by the D.C. Circuit, have developed tests to determine whether a purported nonlegislative rule is, in fact, a legislative rule and, thus, subject to invalidation as procedurally invalid. ${ }^{104}$

Prior to 1978, some courts used a "substantial impact" test to distinguish between legislative and nonlegislative rules, finding that a rule was a legislative rule if it had a substantial impact on the regulated community. ${ }^{105}$ That test, however, received strong criticism and succumbed to the "legally binding effect" or "force of law" test. ${ }^{106}$ The D.C. Circuit has primarily developed the new test, which frames the analysis differently depending on whether the challenged nonlegislative rule is a general statement of policy or an interpretive rule.

For general statements of policy, the court focuses on whether the agency's policy has a binding legal effect. ${ }^{107}$ The court looks at several factors, including whether the agency intended to promulgate a binding rule, ${ }^{108}$ whether the agency used mandatory language in the policy, ${ }^{109}$

102. See Mendelson, supra note 42, at 409 (stating that " $[\mathrm{t}]$ he agency will not . . . receive useful information from previously unknown sources”).

103. See Funk, supra note 5, at 660; Magill, supra note 5, at 1412. Occasionally, when they favor a nonlegislative rule adopted by an agency that the agency has declined to enforce, challengers will forego procedural challenges and argue that nonlegislative rules are legislative rules which the agency must apply. See Funk, supra note 5, at 661.

104. See infra notes 107-10, 113-15; see also Hoctor v. USDA, 82 F.3d 165, 170-72 (7th Cir. 1996).

105. See Cent. Tex. Tel. Coop., Inc. v. FCC, 402 F.3d 205, 214 (D.C. Cir. 2005) (describing past use of this now-disfavored text); Funk, supra note 83, at 1325-26.

106. See Funk, supra note 5, at 662; Johnson, supra note 3, at 705.

107. See Pac. Gas \& Elec. Co. v. Fed. Power Comm'n, 506 F.2d 33, 38 (D.C. Cir. 1974); Franklin, supra note 5, at 288.

108. See U.S. Tel. Ass’n v. FCC, 28 F.3d 1232, 1234 (D.C. Cir. 1994). 
whether the agency has, in practice, applied the policy in a mandatory fashion, ${ }^{110}$ whether the agency characterized its policy as discretionary, ${ }^{111}$ and whether the agency published the policy in the Federal Register or Code of Federal Regulations. ${ }^{112}$

For interpretive rules, the court focuses on whether the rule merely interprets or affirms a preexisting obligation or right from a statute or regulation or, on the other hand, creates a new binding obligation or right. ${ }^{113}$ In assessing the nature of the rule, the court looks at whether the agency cites specific statutory or regulatory authority for the rule, ${ }^{114}$ whether the agency supports the rule with reference to the "language, purpose, and legislative history" of the provision on which it is based, ${ }^{115}$ whether there is an adequate basis in a statute or regulation for the agency's rule, ${ }^{116}$ whether the agency characterizes its actions as creating an interpretive rule, ${ }^{117}$ and whether the agency exercises independent judgment in making policy. ${ }^{118}$ To the extent that the agency engages in independent policymaking, the court will more likely find that the rule is a legislative rule. ${ }^{119}$

Courts, including the D.C. Circuit, have labeled these tests as “'fuzzy,' 'tenuous,' 'blurred,' 'baffling,' and 'enshrouded in considerable smog." "120 Regarding interpretive rules, for instance, the D.C. Circuit has held that an interpretive rule can "resolve...

109. See Appalachian Power Co. v. EPA, 208 F.3d 1015, 1023 (D.C. Cir. 2000). As one commentator observed, a court will be more likely to invalidate a would-be policy statement if it uses “mandatory, definitive language.” Manning, supra note 7, at 918 (quoting Cmty. Nutrition Inst. v. Young, 818 F.2d 943, 947 (D.C. Cir. 1987) (per curiam)) (internal quotation marks omitted).

110. See U.S. Tel. Ass'n, 28 F.3d at 1235 (concluding that the agency's consistent practice revealed an intention for the rule to be binding).

111. See Funk, supra note 5, at 662.

112. See id. at 662-63.

113. See Orengo Caraballo v. Reich, 11 F.3d 186, 195 (D.C. Cir. 1993); Gen. Motors Corp. v. Ruckleshaus, 742 F.2d 1561, 1565 (D.C. Cir. 1984) (en banc).

114. See United Tech. Corp. v. EPA, 821 F.2d 714, 719-20 (D.C. Cir. 1987); Manning, supra note 7 , at 920 .

115. See Gen. Motors Corp., 742 F.2d at 1565; Manning, supra note 7, at 920.

116. See Funk, supra note 83, at 1327-28.

117. Id. at 1330. Courts will give substantial weight to an agency's characterization of a rule as interpretive at the time of issuance. $I d$.

118. See id. at 1328-29; Manning, supra note 7, at 920.

119. See Manning, supra note 7, at 920.

120. Richard J. Pierce Jr., Distinguishing Legislative Rules from Interpretative Rules, 52 ADMIN. L. REV. 547, 547-48 (2000) (quoting Am. Hosp. Ass'n v. Bowen, 834 F.2d 1037, 1046 (D.C. Cir. 1987); Cmty. Nutrition Inst. v. Young, 818 F.2d 943, 946 (D.C. Cir. 1987) (per curiam); Chrisholm v. FCC, 538 F.2d 349, 393 (D.C. Cir. 1976); Noel v. Chapman, 508 F.2d 1023, 1030 (2d Cir. 1975)). 
ambiguities in the statute." ${ }^{121}$ Indeed, interpretive rules would have limited usefulness if agencies could only use them to parrot statutory or regulatory language. Under the D.C. Circuit's test, however, it is then difficult to determine when an agency resolves ambiguities as opposed to creates new rights, thus exercising independent policy judgment. ${ }^{122}$ Similarly, regarding general statements of policy, it is frequently difficult to determine whether a policy has a binding legal effect "in the absence of a well-developed record of enforcement."

Academics too have strongly criticized the test adopted by the D.C. Circuit. ${ }^{124}$ Several academics have proposed a straightforward alternative approach that has been referred to as "the notice-andcomment test" "125 and "ex post monitoring" of nonlegislative rules, ${ }^{126}$ among other names. As Professor William Funk describes the test, "any rule not issued after notice and comment is an interpretive rule or statement of policy, unless it qualifies as a rule exempt from notice and comment on some other basis."127 Agencies can make decisions consistent with the policies and interpretations embodied in the rule even though the agencies did not adopt the rule as a legislative rule. ${ }^{128}$ Because the rule is nonlegislative, however, the agency must justify the reasoning behind the rule when the agency applies it in a concrete, factual context, and the agency cannot simply rely on the rule as the basis for its decision. ${ }^{129}$ If the agency failed to provide an independent rational basis for its decision when it applied the rule, then a reviewing court should invalidate the agency's decision at that time because the agency has not adequately articulated a rational basis for its decision and not because the agency relied on a procedurally invalid legislative rule. ${ }^{130}$ If, on the other hand, the agency articulated a rational basis for its decision that is consistent with the nonlegislative rule, the a reviewing court

121. Health Ins. Ass'n of Am. v. Shalala, 23 F.3d 412, 423 (D.C. Cir. 1994); see Manning, supra note 7 , at $921-22$.

122. See Manning, supra note 7, at 923-25. Manning believes that the D.C. Circuit's precedent "push[es] policymaking upward into more formal, pluralistic, and accountable processes," specifically, notice-and-comment rulemaking. Id. at 916.

123. See Franklin, supra note 5, at 288.

124. See, e.g., Funk, supra note 5, at 663; Seidenfeld, supra note 13, at 352-55.

125. Funk, supra note 5, at 663.

126. Seidenfeld, supra note 13 , at 352-55.

127. Funk, supra note 5, at 663.

128. See Johnson, supra note 3 , at 707.

129. Id. (citing Pac. Gas \& Elec. Co. v. Fed. Power Comm’n, 506 F.2d 33, $38-39$ (D.C. Cir. 1974)).

130. See Elliott, supra note 9, at 1491; Johnson, supra note 3, at 707-08. 
should uphold the agency's decision regardless of the procedures used to adopt the rule. Funk was neither the first nor the last to suggest his "simple test." Professor E. Donald Elliott was an early proponent of the test, ${ }^{131}$ the inspiration for which can be traced back to a dissenting opinion by then-D.C. Circuit Judge Kenneth Starr in $1987 .{ }^{132}$ Professors John Manning, ${ }^{133}$ Jacob Gersen, ${ }^{134}$ and Peter Strauss ${ }^{135}$ have proposed variations of the test, and Franklin recently criticized the test, which he re-branded as the "short cut."136

\section{PROFESSOR FRANKLIN’S CRITIQUE OF THE SHORT CUT}

Like most commentators, Franklin agrees that the tests used to distinguish legislative rules from nonlegislative rules are flawed and difficult to apply. ${ }^{137}$ He further concedes that the short cut is easier to apply $^{138}$ but notes that courts have been reluctant to adopt the approach. ${ }^{139}$ Ultimately, Franklin argues that the status quo is preferable to the short cut. ${ }^{140}$

Franklin stresses that courts, despite ample opportunity, have consistently rejected the short cut in favor of perpetuating the "force of law” and similar tests. ${ }^{141}$ He also argues that courts have not implicitly

131. Elliott, supra note 9, at 1490. Elliott criticized courts for trying to determine whether an agency intended to bind the public with its actions and argued that "it is a fundamental tenet of administrative law, crucial to maintaining the proper balance between courts and agencies, that an agency's action is what it says it is." Id.

132. Cmty. Nutrition Inst. v. Young, 818 F.2d 943, 952 (D.C. Cir. 1987) (Starr, J., concurring in part and dissenting in part), cited in Franklin, supra note 5, at 291-92.

133. Manning, supra note 7, at 918, 929-30. Professor Manning suggests that courts should refrain from attempting to distinguish legislative rules from nonlegislative rules because there are no judicially manageable standards to use to make the distinction. Id. at 929 . This would be consistent, he argues, with the hands-off approach that courts have taken in administering the nondelegation doctrine and in applying Chenery II, both of which lack judicially manageable standards. Id. Like others, Professor Manning stresses that courts will assign different effects to rules when agencies apply them depending on whether the agencies used notice-and-comment rulemaking. Id. at 930-31.

134. See Gersen, supra note 7, at 1719-21.

135. See Peter L. Strauss, The Rulemaking Continuum, 41 DUKE L.J. 1463, 1467-68 (1992).

136. See Franklin, supra note 5, at 278-80.

137. Id. at 278-79.

138. Id. at 279 .

139. Id. at 294.

140. See id.

141. Id. at 294-98. The cases that he cites as examples where a court could have adopted the short cut, but refused to do so, include Warshauer v. Solis, 577 F.3d 1330 (11th Cir. 2009); Catawba County v. EPA, 571 F.3d 20 (D.C. Cir. 2009) (per curiam); Croplife America v. EPA, 329 F.3d 876 (D.C. Cir. 2003); Sprint Corp. v. FCC, 315 F.3d 369 (D.C. Cir. 2003); Air Transport Ass'n of America, Inc. v. FAA, 291 F.3d 49 (D.C. Cir. 2002); General Electric Co. v. EPA, 290 F.3d 377 
adopted the short cut. ${ }^{142}$ If courts routinely rejected pre-enforcement challenges to nonlegislative rules as procedurally invalid legislative rules, he argues, then one might conclude that courts have moved toward replacing the current tests with the short cut. ${ }^{143}$ Unlike many other commentators, ${ }^{144}$ however, Franklin asserts that courts generally review pre-enforcement challenges to nonlegislative rules, rather than dismiss them based on the doctrines of ripeness or finality. ${ }^{145}$ Consequently, he asserts that courts have not implicitly adopted the short cut by postponing review of nonlegislative rules until agencies enforce them in concrete factual settings.

Franklin suggests that courts should continue to apply existing tests to distinguish legislative from nonlegislative rules. ${ }^{146}$ He does not defend all aspects of the current law; but he argues that the current tests' vagueness provides flexibility for courts "to tailor the requirement of notice and comment to circumstances in which factors such as technical complexity or significant effects on regulatory beneficiaries make public input more valuable ... while allowing agencies to dispense with notice and comment when such factors are absent.”147

(D.C. Cir. 2002); Appalachian Power Co. v. EPA, 208 F.3d 1015 (D.C. Cir. 2000).

142. See Franklin, supra note 5, at 299-302.

143. Id. at 300. As he notes, if courts were doing that, "then one of the essential functions of the short cut—preserving agencies' methodological discretion-[would] be[] served." Id. Similarly, he argues that if the tests used to limit pre-enforcement review were "emphatic and predictable," the other essential purpose of the short cut-reducing litigation costs—-would be served as well. Id.

144. See infra notes 155-65, 218-22 and accompanying text.

145. See Franklin, supra note 5, at 300-02. Id. He acknowledges that in "some cases [courts] have held that the question of whether a rule is legislative or nonlegislative is unripe for review at the pre-enforcement stage," but he argues that:

Most of those cases, however, appear to involve claims by an agency that its rule is exempt from notice and comment as a general statement of policy. The finding of unripeness in such cases arises not from the logic of the short cut but from the notion that a rule's true nature as a general statement of policy cannot be ascertained until a series of enforcement actions has revealed whether the position expressed in the rule was tentative or binding on the agency.

Id. at 300. He also acknowledges that some courts have held that nonlegislative rules do not constitute "final agency action" subject to judicial review, but he stresses that "even those courts ... have not come close to embracing the short cut." Id. at 301-02.

146. Id. at 324-26.

147. Id. at 325. Franklin argues that the current reliance on the "force of law" test and similar tests is analogous to "the distinction between facial and as-applied challenges in constitutional adjudication," with the current tests resembling facial review and the short cut resembling as-applied review. Id. Franklin argues that while courts, in the constitutional context, declare a preference for as-applied review, they frequently engage in facial review "because the as-applied model in its strongest form has proven unduly rigid.” Id. at 325. In making that claim, Franklin ignores the fact that courts prefer as-applied review in the constitutional context as he argues for a preference for facial review in the context of distinguishing between legislative and nonlegislative rules. 
More importantly, Franklin argues that the short cut is significantly flawed because it reduces public and judicial oversight over agencies by allowing agencies to avoid notice-and-comment rulemaking. ${ }^{148}$ Franklin and other critics point out that the public has very few opportunities for participation when agencies adopt policies or interpretations through nonlegislative rules. ${ }^{149}$ Although agencies may occasionally consult with regulated entities when developing nonlegislative rules, they rarely consult with regulatory beneficiaries and are not required to consult with anyone. ${ }^{150}$

Supporters of the short cut argue that there is opportunity for public participation when the rule is applied and subsequently challenged in court. Franklin counters that such participation comes too late. ${ }^{151}$ Franklin claims that the lack of early opportunities to participate reduces the likelihood that the agency will develop a sufficient record to facilitate meaningful judicial review, if judicial review is available at all. ${ }^{152}$ Other critics also stress that a much smaller group of persons will participate in review of the rule during the challenge in court than would participate during notice-and-comment rulemaking. ${ }^{153}$

148. Id. at 324; see also Gersen, supra note 7, at 1720 (discussing how agencies might avoid notice and comment); Johnson, supra note 3, at 702-03 (explaining that reliance on nonlegislative rules reduces public opportunity to help develop agency policies or challenge them in court).

149. See Franklin, supra note 5, at 280, 304-05 (discussing the costs of nonlegislative rules). Agencies may seek out input "to gather new information or identify significant problems with [a] policy," to "flush out controversy or political opposition," or to "claim greater legitimacy for their [proposed] polic[y].” Mendelson, supra note 42, at 425.

150. See Mendelson, supra note 42, at 424-28; Seidenfeld, supra note 13, at 341-43 (discussing participation in formulating guidance documents by non-agency entities). As Professor Nina Mendelson notes, to the extent that agencies solicit input on nonlegislative rules, they are likely to seek out regulated entities, rather than regulatory beneficiaries, because agencies are more likely to know the identities of the regulated entities, "may have a greater interest in maintaining a good longterm relationship with regulated entities because [they] must constantly deal with them” and want them to comply with the law, and because regulated entities are likely to have valuable information regarding the cost and feasibility of the agency's proposed rules. Mendelson, supra note 42, at 42930. Regulatory beneficiaries are less likely to have opportunities to provide input to agencies in developing nonlegislative rules because "learning about the existence of guidances before they are finalized can be difficult and expensive,” regulatory beneficiaries may be diffuse and poorly organized, and regulatory beneficiaries "may lack the political clout that might otherwise motivate an agency to seek their approval." Id. at 430. As regulatory beneficiaries are excluded from the decision-making process, they are "less likely to view agency choices as legitimate.” Id. at 420.

151. Franklin, supra note 5, at 316-18 (discussing the different levels of public participation between notice and comment and judicial review as well as differences in judicial review of rules developed with notice and comment and those developed without); see Seidenfeld, supra note 13, at 342-43 ("[O]nce an agency has committed to guidance, the likelihood of participation altering its assessment of whether the guidance is worthwhile is small.”).

152. Franklin, supra note 5, at 316-18.

153. See, e.g., Mendelson, supra note 42, at 450-52 (discussing the difficulties and costs of filing 
Public participation is vital to the development of an agency's policies because (1) it provides oversight of agency action and prevents agencies from being captured by the regulated community or other special interest groups; (2) it provides the agency with important information about the impacts of proposed decisions that enable the agency to administer the law in a rational, defensible manner; and (3) it instills a sense of legitimacy in the public regarding the agency's decisions. ${ }^{154}$

Regarding judicial review, critics of the short cut frequently assert that it eliminates or reduces opportunities for judicial review of an agency's policy decisions. Nonlegislative rules might avoid judicial review either because the rules are not "final agency action" or the challenges are unripe. ${ }^{155}$ Under the APA, a court may review "final agency action." 156 The Supreme Court has held that an agency action is final if it is "the 'consummation' of the agency's decision-making process" "157 and is an "action ... by which 'rights or obligations have been determined,' or from which 'legal consequences will flow.",'158 The Court has limited the second part to cases where agency action "is sufficiently direct and immediate,' and has 'a direct effect on . . . day-today business.”159 Nonlegislative rules that issue from lower-level agency

suit to obtain review of agency policies).

154. Johnson, supra note 3, at 702-03 (footnote omitted).

155. Mendelson, supra note 42, at 420-21. Mendelson has argued that regulatory beneficiaries are likely to have much less access to judicial review of agencies' nonlegislative rules than regulated entities. See id. at 421-24. Mendelson notes that while regulated entities can challenge nonlegislative rules when the agency enforces them, regulatory beneficiaries cannot because the agency will not enforce the rules against them. Id. at 421. She also argues that procedural rules regarding intervention may preclude or limit the ability of regulatory beneficiaries to participate in lawsuits where an agency enforced the nonlegislative rule against regulated entities. Id. at 422-24. Further, she points out that regulatory beneficiaries may not even be aware of enforcement actions involving the nonlegislative rule. Id. at 424.

While recognizing that nonlegislative rules may limit the availability of review for regulatory beneficiaries, Professor Funk argues that the concepts of ripeness and finality provide enough flexibility to grant access to judicial review in some circumstances when it would not be available for regulated entities. See Funk, supra note 83, at 1340. Since regulatory beneficiaries could not challenge a nonlegislative rule in an enforcement action, Funk reasons that " $\mathrm{t}]$ he issue will never become more ripe" for review from the perspective of a regulatory beneficiary that has been deprived of benefits. Id.

156. 5 U.S.C. $\$ 704$ (2006).

157. Bennett v. Spear, 520 U.S. 154, 177-78 (1997) (quoting Chi. \& S. Air Lines v. Waterman S.S. Corp., 333 U.S. 103, 113 (1948)).

158. Id. at 178 (quoting Marine Terminal Ass'n v. Rederiaktiebolaget Transatlantic, 400 U.S. 62, $71(1970))$.

159. See Franklin v. Massachusetts, 505 U.S. 788, 796-97 (1992) (alteration in original) (quoting Abbott Labs. v. Gardner, 387 U.S. 136, 152 (1967)) (internal quotation marks omitted); William Funk, Legislating for Nonlegislative Rules, 56 ADMIN. L. REV. 1023, 1030 (2004). 
officials or leave agency officials with significant discretion may not constitute the consummation of the agency's decision-making process. ${ }^{160}$ Similarly, since nonlegislative rules are generally not binding, courts might determine that the rules will not have a direct effect on challengers. ${ }^{161}$

Nonlegislative rules might also avoid judicial review when courts dismiss challenges based on ripeness. To determine ripeness, the Supreme Court has held that courts should examine the fitness of the issue for resolution and the hardship on the parties of withholding review. ${ }^{162}$ When it is not clear how an agency will apply a nonlegislative rule on a case-by-case basis, courts may conclude that the challenge to the rule is not fit for review. ${ }^{163}$ Similarly, to the extent that a nonlegislative rule is not binding, courts may conclude that there is not sufficient hardship on the challenger to permit review. ${ }^{164}$ In either case, courts may dismiss the challenges to nonlegislative rules as unripe. ${ }^{165}$ Although Franklin argues that most challenges to nonlegislative rules are reviewable, ${ }^{166}$ he asserts that a few important types of nonlegislative

160. See Funk, supra note 83, at 1335-36 (stating that a letter sent by a person lacking "power to render definitive agency interpretations” may not be an agency action); Mendelson, supra note 42, at 411 (noting that a staff-level document might not qualify as "final agency action”).

161. See Johnson, supra note 3, at 712-13 (explaining that nonlegislative rules often are not reviewable because they do not have a direct effect and thus are not "final"). Nevertheless, some nonlegislative rules can have direct, practical effects on persons even though the rules are not binding. See Funk, supra note 83, at 1338 (discussing the practical effects of an agency's nonbinding opinion letter).

162. Abbott Labs., 387 U.S. at 148-49.

163. See Funk, supra note 83, at 1339 (citing Fla. Power \& Light Co. v. EPA, 145 F.3d 1414 (D.C. Cir. 1998)). In Florida Power \& Light Co., the court decided that an interpretation that lacked concrete application was unripe. $I d$.

164. See id. at 1338-39 (discussing instances where courts have concluded that interpretive, nonbinding rules did not impose duties or burdens on a challenger and, thus, did not impose hardship on the challenger).

165. Johnson, supra note 3, at 713 ("[T]o the extent that nonlegislative rules are nonbinding and may be tentative, pre-enforcement challenges to those rules are often dismissed as unripe.” (citing ACLU v. FCC, 823 F.2d 1554, 1577 (D.C. Cir. 1987))).

166. See Franklin, supra note 5, at 301. Franklin asserts that "the prevailing view is that preenforcement . . challenges are indeed ripe for review.” Id. (citing Cohen v. United States, 578 F.3d 1 (D.C. Cir. 2009), reh'g en banc granted in part, opinion vacated in part, 599 F.3d 652 (D.C. Cir. 2010); Coal. for Common Sense in Gov't Procurement v. Sec'y of Veterans Affairs, 464 F.3d 1306, 1315-16 (Fed. Cir. 2006)) (arguing that most courts will subject nonlegislative rules to judicial review). Further, he writes, "although some courts have held that nonlegislative rules do not constitute 'final agency action[,]' . . . this holding, as with ripeness, hardly applies across the board." See id. (quoting 5 U.S.C. § 704 (2006)). 
rules may evade review. ${ }^{167}$ In those cases, the short cut reduces both public and judicial oversight of agency decision-making.

Supporters of the short cut maintain that agencies will not routinely avoid notice-and-comment procedures if courts adopt the short cut because agencies must independently justify the policies and interpretations in nonlegislative rules when they apply them. ${ }^{168}$ Further, courts may accord nonlegislative rules less deference than legislative rules, ${ }^{169}$ especially in light of the Supreme Court's decision in United States v. Mead Corp. ${ }^{170}$ Thus, even though the agency may avoid the public scrutiny of notice-and-comment rulemaking when adopting a nonlegislative rule, a court will subject the rule to enhanced scrutiny on review. ${ }^{171}$ Supporters of the short cut maintain that, in many cases, this trade off will not be worthwhile to agencies. ${ }^{172}$ Agencies will choose to adopt significant policies and interpretations through legislative rulemaking because the rules will have the force of law and receive Chevron deference. ${ }^{173}$ Ultimately, supporters maintain that the agency should have the choice of "paying now," by adopting a policy or interpretation through notice-and-comment rulemaking, or "paying later," by devoting more time and resources to defending the application of the policy or interpretation. ${ }^{174}$

Franklin, however, disagrees, arguing that the short cut would encourage agencies to avoid notice-and-comment rulemaking even for significant policy decisions and interpretations. ${ }^{175}$ He maintains that agencies will avoid notice-and-comment rulemaking in some cases despite the nonbinding nature of nonlegislative rulemaking because some of the policies and interpretations that agencies adopt by nonlegislative rulemaking will never face a challenge in court, whereas they would if

167. See infra notes $180-82$ and accompanying text.

168. Franklin, supra note 5, at 280 (citing Gersen, supra note 7, at 1720-21).

169. Id.

170. 533 U.S. 218 (2001); see Franklin, supra note 5, at 280, 293-94 (explaining that Mead held that "nonlegislative rules are presumptively disqualified from deferential judicial review under the Chevron doctrine"); Gersen, supra note 7, at 1720-21 (asserting that Mead suggests that the degree of deference that a nonlegislative rule receives from a court depends on the agency's procedure used to generate the rule).

171. Franklin, supra note 5, at 280.

172. Id.

173. Id.

174. See Elliott, supra note 9, at 1491. Professor Elliott notes that agencies face the same dilemma as the consumers in the classic Fram oil filter television commercial who are told that "you can pay me now or pay me later." Id.

175. See Franklin, supra note 5, at 312-16. 
the agency adopted them as legislative rules. ${ }^{176}$ In addition, he maintains that agencies will avoid notice-and-comment rulemaking-even though courts accord legislative rules with Chevron deference-because agencies can adopt policies and interpretations through adjudication or nonlegislative rulemaking and receive the same or nearly the same deference for their decisions in court. ${ }^{177}$ As a result, he maintains that the short cut reduces public and judicial oversight of agency decisionmaking. ${ }^{178}$ Finally, Franklin argues that even in cases where a party may challenge an agency's nonlegislative rule in court, the nature of the public and judicial oversight of agency decision-making at that stage differs significantly from the oversight in the notice-and-comment process and pre-enforcement review of legislative rules. ${ }^{179}$

Regarding judicial review, Franklin notes that when an agency's nonlegislative rule outlines conditions under which the agency will withhold enforcement actions, opponents will not be able to challenge the rule in an enforcement action because the agency will not bring an enforcement action under the rule. ${ }^{180}$ These deregulatory or nonenforcement policies frequently have a greater negative impact on regulatory beneficiaries than on regulated entities. ${ }^{181}$ Franklin also points out that many other nonlegislative rules are unlikely to be challenged if they cannot be challenged pre-enforcement. Regulated entities may decide that the costs of challenging the rule in an enforcement actioncombined with potential penalties for noncompliance and damage to their relationship with the agency-exceed the benefits that may arise from successfully challenging the rule. ${ }^{182}$ Franklin argues that when an agency can "coerce compliance" or adopts policies to deregulate or limit enforcement, it succeeds in avoiding both public and judicial oversight. $^{183}$

Regarding alternatives to legislative rulemaking, Franklin argues that the short cut would allow agencies to routinely avoid legislative

\footnotetext{
176. Id. at 308-11.

177. See id. at 312-16; infra text accompanying notes 184-93.

178. See Franklin, supra note 5, at 316.

179. See id. at 316-19; infra text accompanying notes 195-96.

180. See Franklin, supra note 5, at 308-09; see also Funk, supra note 5, at 667; Seidenfeld, supra note 13 , at 344 . The nonlegislative rule may set minimum criteria that trigger enforcement, may outline safe harbors for compliance, or may articulate a general deregulatory policy or interpretation. See Franklin, supra note 5, at 309.

181. See Franklin, supra note 5, at 309-11.

182. See id. at 311-12; see also Seidenfeld, supra note 13, at 343.

183. See Franklin, supra note 5, at 309.
} 
rulemaking even for significant policy decisions because agencies can still receive substantial deference when they adopt policies and interpretations through adjudication and nonlegislative rulemaking. ${ }^{184}$ First, under Chenery II, courts are reluctant to impede on agencies' discretion to choose to implement policies and interpretations through adjudication, as opposed to legislative rulemaking. ${ }^{185}$ Since courts will accord Chevron deference to policies and interpretations adopted by agencies through formal adjudication, he argues, agencies may frequently choose to proceed through adjudication rather than legislative rulemaking. ${ }^{186}$

Franklin also argues that, even after Mead, an agency may choose to adopt significant policies and interpretations as nonlegislative rules because courts will accord those rules Chevron deference. ${ }^{187}$ He stresses that Mead merely created a presumption that nonlegislative rules should receive less deference; further, in Barnhart $v$. Walton, ${ }^{188}$ the Supreme Court confirmed that nonlegislative rules may receive Chevron deference in some cases. ${ }^{189}$ If nonlegislative rules receive the same deference from courts, he reasons, then agencies trade off nothing by making policy through nonlegislative rules rather than legislative rules. ${ }^{190}$ Even under the Skidmore standard, Franklin argues that agencies trade off little because the Skidmore and Chevron standards are, in practice, almost identical. ${ }^{191}$ Finally, Franklin notes that when an agency interprets a

\footnotetext{
184. See id. at 312.

185. Id.

186. Id. at 312-16. Franklin concedes that there are disadvantages to agencies in proceeding through adjudication, since the decision adopted through adjudication will only bind the parties to the adjudication and the agency will have to justify future applications of the policy in future adjudications to the extent that the facts in the adjudications are distinguishable from the original adjudication. Id. at 312-13. Nevertheless, he suggests that those limitations are minor and will not generally discourage agencies from proceeding through adjudication instead of legislative rulemaking. Id.

187. Id. at 320-22.

188. 535 U.S. 212 (2002).

189. See Franklin, supra note 5, at 320. Franklin notes that in Mead, "the Court conceded that it had accorded Chevron deference to some nonlegislative rules in the past and suggested that it might do so again.” Id. (footnote omitted) (citing United States v. Mead Corp., 533 U.S. 218, 231 (2001)). Franklin continues by explaining that "in Barnhart, the Court went out of its way to reject the claimant's argument that the agency's interpretation was not entitled to deference because it had initially been issued without notice and comment." Id.

190. See id. at 320-23 (discussing Mead and myriad deference regimes).

191. Id. at 321-22. Franklin argues that the Skidmore standard is particularly deferential "in technical contexts where courts are likely to view agencies as having a comparative advantage in expertise." Id. at 321. He notes that "[a] recent study demonstrated that agencies prevailed in more than sixty percent of the cases in which the Skidmore standard was applied.” Id. (citing Kristin E.
} 
regulation, rather than a statute, through a nonlegislative rule, courts will accord the agency's rule even greater deference than Chevron deference. ${ }^{192}$ Under Supreme Court precedent, courts will uphold an agency's interpretation of its own regulation unless it is "plainly erroneous or inconsistent with the regulation."193 Based on the standards of review, Mead does not give agencies an incentive to choose legislative rulemaking over other policymaking tools. ${ }^{194}$

Even if the short cut works as supporters claim, and agencies choose to adopt policies and interpretations as nonlegislative rules knowing that they will have to "pay later" by independently justifying their decisions before a court according them less deference, Franklin raises an additional criticism. The short cut, he argues, would still reduce public and judicial oversight of agency decision-making because "the public scrutiny that comes with notice and comment and the judicial scrutiny that comes with post-enforcement review are fundamentally dissimilar." ${ }^{195}$ He stresses that

the mechanism of notice and comment was designed to ensure an opportunity for interested members of the public to participate in the process of agency policymaking by making comments, raising objections, and suggesting alternatives to proposed rules. While postenforcement judicial review can mimic these features, it cannot fully recreate them because it occurs in the factual context of a particular enforcement action, before generalist judges, and at the behest of the regulated entity against whom that action has been taken .... [E]ven with liberal intervention standards, the "facts and arguments submitted" at the post-enforcement stage are likely to exclude some that would have been aired during the process of notice and comment. ${ }^{196}$

Hickman \& Matthew D. Krueger, In Search of the Modern Skidmore Standard, 107 CoLuM. L. ReV. 1235, 1259-60, 1275 (2007)).

192. Id. at 322-23. Franklin maintains that this has broad impacts because much, if not most, agency policymaking involves interpretations of regulations rather than statutes. See id. at 323.

193. Id. at 322 (quoting Bowles v. Seminole Rock \& Sand Co., 325 U.S. 410, 414 (1945)) (internal quotation marks omitted). This is Seminole Rock deference. See id.

194. See id. at 324.

195. See id. at 316.

196. Id. at 316-17 (footnote omitted). Franklin recognizes that cynics contend that notice-andcomment rulemaking does not truly foster public participation-since rules adopted through that process are effectively finalized before the process even begins - but rather simply compiles a record for judicial review. Id. at 317 (citing Elliott, supra note 9, at 1495). Even viewing it in that light, however, Franklin argues that "robust public participation in notice and comment enhances the later process of judicial review by bringing to light technical issues that generalist judges might not otherwise spot, thereby enabling courts to engage in meaningful scrutiny of the resulting rules." Id. at 318. 
In this way, the short cut reduces the opportunity for regulatory beneficiaries to participate in agency policymaking significantly more than it reduces the opportunity for regulated entities to participate. ${ }^{197}$ Therefore, Franklin supports the courts' rejection of the short cut and maintenance of the status quo. ${ }^{198}$

\section{PROFESSOR SEIDENFELD's DEFENSE OF THE SHORT CUT, AS MODIFIED}

Seidenfeld, on the other hand, criticizes both the status quo, which he labels "the 'legal-effect school,"” and the short cut. ${ }^{199}$ Regarding the legal effect school, he argues that the APA authorizes agencies to issue nonlegislative rules that have some force, and thus, it is inappropriate for courts to strike down nonlegislative rules based on a determination that they are binding. ${ }^{200}$ More importantly, however, he argues that the tests used to distinguish legislative rules from nonlegislative rules are unmanageable. $^{201}$ Because nonlegislative rules always involve some lawmaking and may have some binding effect, Seidenfeld deems unworkable those tests that treat rules as legislative simply if they are binding or involve agency lawmaking. ${ }^{202}$ The tests sweep too broadly, discourage all nonlegislative rulemaking, and can encourage agencies to make policy through adjudication instead. ${ }^{203}$ According to Seidenfeld, if courts use tests to discourage agencies from using nonlegislative rulemaking, then the tests should focus on discouraging agencies from using nonlegislative rulemaking in inappropriate situations, rather than discouraging all nonlegislative rulemaking. ${ }^{204}$ Even if the current tests

197. Id. at 319 (stressing that regulatory beneficiaries often submit comments to agencies through notice-and-comment rulemaking "but ... are generally unable to obtain judicial review of permissive or threshold-setting nonlegislative rules”).

198. To be fair, Franklin does criticize the current doctrine's ambiguities and the courts' bias toward procedural formality. He does not, however, advocate significant change. See id. at 325-26.

199. See Seidenfeld, supra note 13, at 364.

200. See id. at 351. Seidenfeld suggests that the APA implies that guidance documents can have some effect because it provides 'that an agency cannot use a guidance document 'against a party' unless the document was published in the Federal Register or was made available to the public and the party had actual knowledge of its terms." Id.

201. Id.

202. Id. at $351-52$.

203. Id.

204. See id. at 351-52 ("[J]udicial review under the legal-effect school ... can result in judicial reversal of many valuable guidance documents.”). Seidenfeld argues that the propriety of adopting a policy or interpretation without notice and comment should "turn on balancing the costs and benefits of proceeding by nonlegislative rulemaking," which depends on "such context-specific factors as the 
do not discourage all nonlegislative rulemaking, Seidenfeld argues that they discourage nonlegislative rulemaking in cases where it would be most effective. ${ }^{205}$ For instance, under current tests, policy statements are more likely to be invalidated if they are detailed and definitive. ${ }^{206}$ Those $^{2}$ are, however, the types of policy statements that would provide the most guidance to agency staff and the regulated community. ${ }^{207}$ Similarly, as an interpretive rule strays further from the precise language of the statute or regulation that it interprets, it becomes more likely that a court will invalidate it. ${ }^{208}$ If an interpretive rule merely parrots the language of the statute or regulation, however, then there is little need for the rule in the first $_{\text {place. }}{ }^{209}$

Seidenfeld also identifies deficiencies with the short cut. $^{210}$ Specifically, he agrees with Franklin's contention that the short cut could restrict stakeholder participation in agency policymaking and reduce opportunities for judicial review of agency policies. ${ }^{211}$ Ultimately, however, Seidenfeld concludes that the short cut, as modified by several proposed reforms, is preferable to the status quo. ${ }^{212}$

His article argues that courts should modify the ripeness and finality analyses to allow immediate challenges to nonlegislative rules upon their issuance and that the challenges should focus on the substance of the rule, rather than the procedures used to adopt it. ${ }^{213}$ He advocates for "meaningful" review of the rules under a modified arbitrary-andcapricious standard, which would require agencies to provide a more detailed explanation for the nonlegislative rule's basis at the time the agency issues it. ${ }^{214}$

\footnotetext{
interference with reliance interests, the importance of information known to stakeholders but not to the agency, the benefits from implementing the policy or interpretation quickly, and the ability of the agency to devote resources to other action.” Id. at 351-52. At the same time, though, he notes that courts are not well-equipped to conduct such analysis. Id. at 359-60.

205. Id. at 360 ("[T] the extent that judicial doctrine signals any message to agencies, it is to avoid guidance precisely when guidance is likely to be most valuable.”).

206. Id. at 359-60.

207. Id.

208. Id.

209. See id.

210. Id. at 357.

211. See id. ("[M]any guidance documents are never subjected to ex post review. Regulated entities face incentives to comply with them rather than challenge them ex post.... [A]gencies are unlikely to be affected by [stakeholder] participation after the guidance is announced.”).

212. See id. at 373 ("My proposal ... is to add some version of direct substantive review to the elimination of ex ante procedural review.").

213. See id. at 373-74.

214. See id. at 373-74, 392-94.
} 
Seidenfeld discusses a proposal by Magill to review agencies' choice of nonlegislative rulemaking over legislative rulemaking under a more stringent standard ${ }^{215}$ and a proposal by Professor Nina Mendelson to allow stakeholders to petition agencies to issue, modify, or repeal certain nonlegislative rules. ${ }^{216} \mathrm{He}$ concludes that both proposals are deficient. ${ }^{217}$ Unlike Franklin, Seidenfeld believes that the doctrines of ripeness and finality provide significant barriers to judicial review of nonlegislative rules, and he argues that Magill and Mendelson's proposals would not make it easier to challenge nonlegislative rules. ${ }^{218}$ He also argues that the two reform proposals will increase agencies' resource demands, which may discourage the appropriate use of nonlegislative rulemaking. ${ }^{219}$ Finally, he criticizes both proposals as failing to provide a sufficiently rigorous standard of review for nonlegislative rules. ${ }^{220}$ Seidenfeld's proposal attempts to avoid the shortcomings of the Magill and Mendelson proposals. ${ }^{221}$

215. Id. at 364-65 (citing Magill, supra note 5, at 1413-25).

216. Id. at 365 (citing Mendelson, supra note 42, at 443-44).

217. See id. at 364-66.

218. See id. at 365-66. Seidenfeld argues that, prior to enforcement, guidance documents may not alter legal rights and obligations or impose hardship on regulated entities or regulatory beneficiaries. Id. at 366 (citing Ctr. for Auto Safety v. Nat'l Highway Traffic Safety Admin., 452 F.3d 798, 808 (D.C. Cir. 2006); Indep. Equip. Dealers Ass'n v. EPA, 372 F.3d 420, 427 (D.C. Cir. 2004)). Therefore, such guidance documents are not final agency action, and challenges to them are not ripe. Id. (citing Molycorp. Inc. v. EPA, 197 F.3d 543, 547 (D.C. Cir. 2004)).

219. Id. at 367. Regarding Magill's proposal, Seidenfeld argues that it would be very time consuming for agencies to explain why they chose to issue each guidance document as a guidance document, rather than as a legislative rule, when agencies issue tens of thousands of guidance documents each year. Id. (citing Strauss, supra note 135, at 1568-69). Seidenfeld notes that Mendelson's petition proposal could require agencies to use notice-and-comment procedures when petitioned to repeal or amend a guidance document. Id. at 367-68 (citing Mendelson, supra note 42, at $439 \&$ n.223). Those procedures, Seidenfeld notes, would be costly and time consuming. Id.

220. Id. at 367-72. Seidenfeld asserts that courts are not likely to provide rigorous review of agencies' choice of policymaking tools or refusal to modify or repeal a guidance document because those agency decisions involve agencies' considerations of priorities for limited resources, and courts generally defer to agencies in that area. Id. at 367. For instance, while the APA authorizes persons to petition agencies to issue, modify, or repeal rules, courts offer substantial deference to agencies' decisions to deny such petitions, even though the courts apply, in theory, the arbitrary-andcapricious standard of review. Id. at 368-69.

221. Regarding Mendelson's proposal, Seidenfeld also argues that empirical evidence suggests that the proposal "would have little effect on agency misuse of guidance documents." Id. at 370-71. Seidenfeld argues that because nonlegislative rules are "rules" under the APA, those wishing to challenge guidance documents can already petition agencies to amend or repeal these "rules" under the APA, but few have done so. Id. (citing 5 U.S.C. $\S 553$ (2006)). Since the availability of an existing petition process has had little effect on agencies' use of guidance, Seidenfeld argues, there is no reason to believe that a new petition process will have any greater impact. Id. Mendelson, however, argues that the existing petition process has not reduced the misuse of guidance documents because it does not apply to guidance documents; Seidenfeld responds that the case law does not 
To reduce the barriers to judicial review, Seidenfeld advocates for a modification of the doctrines of ripeness and finality to facilitate immediate judicial review of a rule at its adoption. ${ }^{222}$ "[I]mmediate review ... relieves regulated entities from the dilemma of whether to comply with regulations that they believe to be invalid or risk significant penalties for noncompliance"223 and could "encourag[e] agencies to consult with stakeholders who are not repeat players or politically powerful groups when developing guidance."224

Seidenfeld recognizes, however, that those doctrines protect agencies from a flood of lawsuits that could raise the cost of policymaking through nonlegislative rules and "unduly chill" its use. ${ }^{225}$ Thus, Seidenfeld argues that one must narrowly tailor modifications to the doctrines to discourage the improper use of guidance documents without eliminating their appropriate use. ${ }^{226}$

Regarding final agency action, Seidenfeld proposes that courts should examine whether an agency is actively considering a change in the challenged policy, rather than how likely it is that the policy will be changed, when determining if it is "the consummation of the agency's decisionmaking process.”227 More significantly, Seidenfeld argues that courts simply should not apply the second part of the "final agency action" test-which focuses on whether an agency's action determines rights and obligations or generates legal consequences - to nonlegislative rules. $^{228}$ Regarding ripeness, Seidenfeld suggests that nonlegislative

clearly support Mendelson's claim. Id. at 371 (citing Mendelson, supra note 42, at 439-40).

222. Id. at 375 .

223. Id. at 373-74 (citing Abbott Labs. v. Gardner, 387 U.S. 136, 152-53 (1967)). Therefore, regulated entities "can obtain a judicial determination of [the document's] validity prior to having to comply.” Id. at 374.

224. Id. at 384-85.

225. Id. at 375 .

226. See id.

227. Id. at 375 (quoting Bennett v. Spear, 520 U.S. 154, 177-78 (1997)) (internal quotations marks omitted). Similarly, Seidenfeld argues that a guidance document that takes effect without further agency action should suffice as such consummation even though a subordinate official, and not the agency head, issued the document. Id. at 376-77. While subjecting guidance from lowerlevel agency officials to immediate judicial review could significantly increase the costs to the agency of using guidance documents, Seidenfeld suggests that agencies could minimize those costs by adopting a procedural rule that requires challengers as to those lower level guidance documents to petition the agency for reconsideration before filing suit. Id. at 375-78. While the petition is pending, the lower-level guidance document would not constitute final agency action. Id. at 378 (citing 5 U.S.C. § 704 (2006); Darby v. Cisneros, 509 U.S. 137, 152 (1993)).

228. Id. at 379-380. Seidenfeld questions whether the second prong of the final agency action test should even apply in cases involving challenges to legislative rules. Id. Further, he argues that the "second prong of the finality doctrine has no logical relation to the aim of preventing 
rules that are "pragmatically binding"-that is, likely to affect the behavior of regulated entities-have ripened for judicial review, even though the rules are not legally binding. ${ }^{229}$

Once the barriers to judicial review recede, Seidenfeld argues that courts should adopt a variant of the "reasoned decisionmaking" standard when reviewing nonlegislative rules. ${ }^{230}$ He suggests that review for reasoned decision-making would encourage agencies to solicit broader stakeholder input and carefully consider relevant information before acting. ${ }^{231}$ He admits that review for reasoned decision-making is difficult when the agency does not create a record of its action, as is generally the case for nonlegislative rules. ${ }^{232} \mathrm{He}$ also recognizes that imposing a record requirement on nonlegislative rulemaking could ossify that process and discourage its use. ${ }^{233}$ He does not advocate simply

unnecessary judicial intervention into ongoing agency rulemaking.” Id. at 380. In an earlier article, Funk advocated an even broader change than Seidenfeld, proposing that Congress should amend the APA to define "final agency action" to include "any interpretive rule or general statement of policy." See Funk, supra note 159, at 1025 (internal quotation marks omitted) (section 3(a)(2) of the proposed APA amendment).

229. See Seidenfeld, supra note 13, at 380 ("Courts should not impose a requirement that a policy statement be so clear as to specify precisely how the policy will operate before it can be challenged. Nor should they find a document unripe because the agency has indicated that it retains discretion about whether and when to apply it."). Seidenfeld reasons that "pragmatically binding" guidance documents impose hardship on regulated entities and regulatory beneficiaries sufficient to justify ripeness, even though the documents are not legally binding, because regulated entities frequently will face prosecution and civil and criminal penalties if they fail to comply with the guidance document. Id. at 381. Seidenfeld also notes that "courts often find that arbitrary and capricious challenges to guidance documents are not fit for review" because the "documents do not indicate clearly when and how agencies will apply them.” Id. at 383 (citing Interstate Natural Gas Ass'n of Am. v. FERC, 285 F.3d 18, 58-62 (D.C. Cir. 2002); Fla. Power \& Light Co. v. EPA, 145 F.3d 1414, 1421 (D.C. Cir. 1998); Dietary Supplement Coal., Inc. v. Sullivan, 978 F.2d 560, 563-65 (9th Cir. 1992)). Seidenfeld argues that in most cases, despite precatory language, it is fairly clear how an agency intends to apply a guidance document, so the document should be fit for review despite the equivocal language. Id. at 383-84. Seidenfeld's proposal is similar to a proposal advanced by Funk to amend the APA to provide that "[i]n assessing the ripeness for review of an interpretive rule or general statement of policy, the court shall assess the hardship to the plaintiff in light of the practical consequences of the adoption of the rule or policy.” See Funk, supra note 159, at 1026 (section 3(b) of the proposed APA amendment).

230. See Seidenfeld, supra note 13, at 373-74.

231. Id.

232. See id. For instance, Seidenfeld notes that while courts apply arbitrary-and-capricious standard to review agency denials of petitions to adopt rules, courts do not apply that standard rigorously when the agency has not developed a record to support its decision to deny the petition. Id. at 385-86.

233. Id. at 373-74 (noting that "much of the value of guidance documents stems from the speed and ease with which agencies can issue them"). He further acknowledges that review for reasoned decision-making will add to the time and resource commitment for agencies when they make nonlegislative rules and that full-fledged hard-look review for all agency guidance documents could "discourage issuance even of guidance documents that are valuable.” Id. at 374-75 (citing Strauss, 
treating the information that an agency considered in making a decision as the record for review, as that could encourage the agency to limit its information-collection efforts in order to increase the chances that a court would uphold the agency's decision. ${ }^{234}$ His solution, therefore, imposes a requirement that agencies explain their decisions "in terms of factors that are relevant and alternatives that are plausible given the state of knowledge available to the agency when it acted," regardless of whether anyone suggested those factors or alternatives when the agency developed its nonlegislative rule. ${ }^{235}$ Seidenfeld argues that his approach would encourage more thoughtful development of guidance documents by agencies, ${ }^{236}$ prevent agency abuse of guidance documents, ${ }^{237}$ increase participation by regulatory beneficiaries, ${ }^{238}$ and avoid ossifying the process of developing such documents. ${ }^{239}$

\section{A DIFFERENT PATH}

Seidenfeld correctly calls for the courts to reject the legal effects test; however, his solution inappropriately treats nonlegislative rules like legislative rules and likely creates precisely the disincentive for agencies to adopt nonlegislative rules that he attempts to avoid. The remainder of

supra note 135 , at 1467$)$.

234. Id. at 385-87.

235. Id. at 388. Seidenfeld argues that "agencies would have to acknowledge well-recognized debates in the relevant field about issues of fact and prediction, and explain the substance of interpretations or policies announced in guidance documents in light of its resolution of those issues." Id. He defines "well-recognized debates" with reference to those "who [are] familiar with the underlying predicates for the policy or interpretation," rather than the general public, but not necessarily to include "information privy only to a few stakeholders because of their unique relation to the matter." Id. He stresses that courts should "consider arguments that directly address the accuracy of information and the plausibility of analyses on which the agency relied in formulating the [guidance] document.” Id. at 389.

236. See id. at 390 (“Judicial review can provide a powerful tonic to agency staff members' propensities to take shortcuts and ignore factors that might undermine their predilections about the wisdom of a policy or interpretation.” (citing Richard J. Pierce Jr., Seven Ways to Deossify Agency Rulemaking, 47 ADMIN. L. REV. 59, 68 (1995))).

237. See id. at 385-90.

238. See id. at 392 (reasoning that because review for reasoned decision-making leaves much uncertainty about what factors or alternatives a court will determine an agency should consider, agencies have an incentive to seek out information more broadly so they can consider and address any factors or alternatives that a court may find they were obligated to consider).

239. See id. at 393-94. Seidenfeld argues that his proposal will not ossify the nonlegislativerulemaking process because agencies can choose to use any procedures they deem appropriate to develop the information necessary to withstand judicial review. Id. Further, the proposal does not require agencies to "pay close attention to every detail of every piece of information" they receive, as they must only "explain[] [their] decision[s] in light of information known by those generally familiar with the underlying factual issues related to the matter at hand.” Id. at 393. 
this Article outlines the benefits of the short cut over the legal effects test and proposes an alternative to address criticism that the short cut limits public and judicial oversight of nonlegislative rules.

\section{A. The Benefits of the Short Cut}

The short cut is preferable to the legal effects test because it is easier to apply, provides certainty to regulated entities and beneficiaries regarding the effect of agencies' rules, and promotes judicial economy. Numerous commentators have stressed that the legal effects test is confusing and unworkable, can be applied inconsistently, and may discourage even the appropriate use of nonlegislative rules. ${ }^{240}$ By focusing solely on whether an agency has adopted a rule through noticeand-comment rulemaking and whether an exception to the notice-andcomment requirements applies to the rulemaking, the short cut is much simpler to apply. ${ }^{241}$ The simplicity of the test is valuable to the regulated community and regulatory beneficiaries because it gives them greater certainty regarding the effect of the rule. ${ }^{242}$ Courts will save time and resources in administering the test, as they do not have to determine whether a rule is a legislative or nonlegislative rule until the rule's application. $^{243}$

Contrary to claims made by supporters of the legal effects test, ${ }^{244}$ its uncertainty does not encourage agencies to implement policies and interpretations through the more publicly inclusive and judicially reviewable notice-and-comment rulemaking. Rather, it encourages agencies to make decisions through adjudication, which provides no significant opportunities for public participation. ${ }^{245}$ In addition, when

\footnotetext{
240. See supra Part II.C.

241. See Franklin, supra note 5, at 279; Funk, supra note 5, at 663.

242. See Funk, supra note 5, at 663.

243. See Franklin, supra note 5, at 279.

244. See id. at 302.

245. See id. at 306; Johnson, supra note 3, at 730-33; Manning, supra note 7, at 930; Seidenfeld, supra note 13, at 352-53. While regulated entities and beneficiaries suffer from a lack of participation, agencies also suffer "because [they] cannot access the information that those parties could have provided," which could be useful to the agencies in determining the broader implications of their decisions. See Johnson, supra note 3, at 732. Mendelson notes, however, that agencies still have incentives to adopt policies through nonlegislative rules despite increased costs for adopting guidance. See Mendelson, supra note 42, at 435-37. Agencies may want to give the public advance notice of their position because (1) agencies "may wish to treat regulated entities fairly—or at least to be perceived as treating them fairly"; (2) "an agency’s failure to disclose its policy positions or interpretations would likely undermine its relations with regulated entities"; and (3) "the failure to disclose a particular interpretation of a statute or regulation will interfere with an agency's ability to
} 
agencies make decisions through adjudication, the public receives less advance notice regarding the agencies' policies and interpretations than when agencies adopt those policies and interpretations as nonlegislative rules. ${ }^{246}$ Indeed, a regulated entity may be unaware of an agency's position until the agency enforces it against it in adjudication. In most cases, the legal effects test simply delays the inevitable application of the agencies' policies and interpretations. ${ }^{247}$

Funk identifies another undesirable impact of the legal effects test. Regulated entities or future courts may misinterpret an initial court's invalidation of a nonlegislative rule on procedural grounds as judicial invalidation of the underlying substance of the rule. ${ }^{248}$ This might also drive agencies to mistakenly abandon a valid policy or interpretation without soliciting further public input. ${ }^{249}$ When courts invalidate a nonlegislative rule on procedural grounds under the legal effects test, they have not adjudicated the substantive validity of the rule, and thus, agencies should retain the authority to adopt the same interpretation or policy through adjudication or notice-and-comment rulemaking. ${ }^{250}$

The short cut avoids this confusion and adheres to congressional intent by preserving an agency's discretion to choose its policymaking tool. ${ }^{251}$ When Congress intends to require an agency to adopt policies or interpretations through notice-and-comment rulemaking or adjudication, it does so explicitly. ${ }^{252}$ When Congress has not expressly limited an agency's discretion to choose the appropriate policymaking tool, Chenery II counsels that a court should not limit that discretion. ${ }^{253}$ The legal effects test limits an agency's discretion by treating nonlegislative rules as invalid legislative rules. A superior approach recognizes that an agency may announce its policies and interpretations in nonlegislative

obtain penalties for statutory or regulatory violations.” See id. at 435-36.

246. See Franklin, supra note 5, at 306-07; supra notes 97-98 and accompanying text. Professor Franklin concedes that "one of the benefits of nonlegislative rulemaking, at least in contexts where notice and clarity are especially important, is that it is not pure adjudication.” Id. at 306. Proceeding through adjudication also reduces the opportunity for agencies to implement laws and regulations consistently by providing advance guidance to agency employees. See Johnson, supra note 3, at 728.

247. See Seidenfeld, supra note 13, at 360-62.

248. See Funk, supra note 5, at 664-65.

249. See Franklin, supra note 5, at 302.

250. See Funk, supra note 5, at 665.

251. See Franklin, supra note 5, at 300.

252. See supra notes $35-36$ and accompanying text.

253. See supra notes 72-78 and accompanying text; see also Johnson, supra note 3, at 730-32. 
rules, so long as it provides adequate justification upon their application in concrete factual settings.

\section{B. Responding to Professor Franklin's Criticisms of the Trade Off and the Short Cut}

Supporters of the short cut maintain that agencies may occasionally trade the binding effect and Chevron deference that comes with legislative rulemaking for the low cost and flexibility of nonlegislative rulemaking. ${ }^{254}$ Even so, the supporters argue, many situations will encourage agencies to adopt rules through notice-and-comment rulemaking in a short cut regime so that the agencies' policies and interpretations will have binding effect and receive Chevron deference. ${ }^{255}$ Franklin argues that agencies will not have an incentive to adopt rules through notice-and-comment procedures in a short cut regime for the following reasons: (1) courts will extend Chevron deference to nonlegislative rules; (2) even if courts apply Skidmore deference to nonlegislative rules, Skidmore deference is equivalent to Chevron deference; and (3) courts accord more deference than required by Chevron to nonlegislative rules that interpret legislative rules. ${ }^{256}$ Each argument, however, contains flaws.

Although the Supreme Court has been reluctant to create a brightline rule that precludes the extension of Chevron deference to nonlegislative rules, the Court has not yet found a nonlegislative rule that has deserved such deference. ${ }^{257}$ In Christensen v. Harris County, the Court determined that Skidmore deference, rather than Chevron deference, applied to an opinion letter from an official with the Department of Labor. ${ }^{258}$ The Court reasoned that "[i]nterpretations such as those in opinion letters-like interpretations contained in policy statements, agency manuals, and enforcement guidelines, all of which lack the force of law-do not warrant Chevron-style deference.”259 The

\footnotetext{
254. See supra notes 168-74 and accompanying text.

255. See supra notes $168-74$ and accompanying text.

256. See supra notes 175-79, 187-94 and accompanying text.

257. Consequently, Professor Funk has proposed that Congress should amend the APA to explicitly provide that the Skidmore test is the appropriate standard for review of nonlegislative rules. See Funk, supra note 159, at 1041-42.

258. 529 U.S. 576, 587 (2000).

259. Id. (citing Reno v. Korny, 515 U.S. 50, 61 (1995); EEOC v. Arabian Am. Oil Co., 499 U.S. 244, 256-58 (1991); Martin v. Occupational Safety \& Health Review Comm’n, 499 U.S. 144, 157 (1991)).
} 
following year, in Mead, the Court held that Chevron did not apply to review of a tariff classification by the United States Customs Service. ${ }^{260}$ The Court held that Chevron applies "when it appears that Congress delegated authority to the agency generally to make rules carrying the force of law, and that the agency interpretation claiming deference was promulgated in the exercise of that authority."261 According to the Court, a "[d]elegation of [that] authority may be shown in a variety of ways, as by an agency's power to engage in adjudication or notice-and-comment rulemaking, or by some other indication of a comparable congressional intent.,262

While those cases seemed to suggest that decisions lacking the force of law, like most nonlegislative rules, should not receive Chevron deference, the Court has refused to directly foreclose on the availability of such deference for all nonlegislative rules. In Barnhart v. Walton, the Supreme Court seemed to modify the test used to determine when Chevron applies. There, the Court considered "the interstitial nature of the legal question, the related expertise of the Agency, the importance of the question to the administration of the statute, the complexity of that administration, and the careful consideration the Agency has given the question over a long period of time" to determine whether Chevron applied to regulations adopted by the Social Security Administration. ${ }^{263}$ Although the Court stressed "the fact that the Agency previously reached its interpretation through means less formal than 'notice and comment' rulemaking [did] not automatically deprive that interpretation of the judicial deference otherwise its due.”264 The Barnhart Court ultimately reviewed the legislative rule adopted by the Social Security Administration, rather than the nonlegislative rule that preceded it, so the Court's discussion of the deference accorded nonlegislative rules is mere dicta. $^{265}$

Although Franklin argues that courts in fact accord the same deference under both Chevron and Skidmore, many commentators

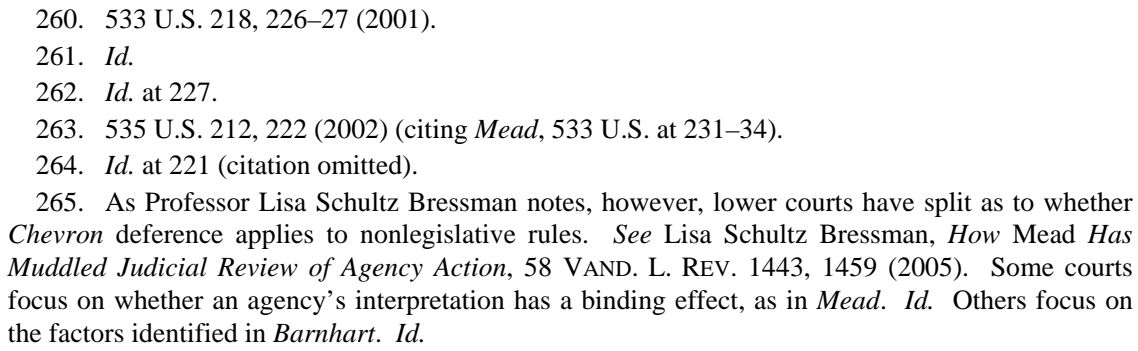
Muddled Judicial Review of Agency Action, 58 VAND. L. Rev. 1443, 1459 (2005). Some courts focus on whether an agency's interpretation has a binding effect, as in Mead. Id. Others focus on the factors identified in Barnhart. Id. 
disagree. ${ }^{266}$ In fact, empirical studies illustrate clear differences in application between the standards. ${ }^{267}$ In an empirical study of federal cases decided in the six months following Mead, Eric Womack found that courts upheld the agency's decision when applying the Skidmore test only thirty-one percent of the time. ${ }^{268}$ Professor Amy Wildermuth examined a different set of post-Mead federal court decisions and found that courts upheld the agency's decision under Skidmore only thirty-nine percent of the time. ${ }^{269}$ In contrast, most empirical studies focusing on Chevron review either before or after Mead find that courts uphold agencies' decisions under Chevron between sixty and seventy percent of the time. ${ }^{270}$

In a recent article, Professor David Zaring reviewed several empirical studies of judicial application of Chevron, Skidmore, the arbitrary-and-capricious standard, hard-look review, the substantialevidence standard, and de novo review of agencies' actions. ${ }^{271}$ Zaring concluded that courts affirm agencies' decisions at roughly the same rate, regardless of which standard the courts apply. ${ }^{272}$ In his article, he cited a review of Skidmore cases conducted by Professor Kristin Hickman and Matthew Krueger that found courts upheld the agencies' interpretation in nearly sixty-one percent of the cases. ${ }^{273}$ The rate of affirmance in the

266. See, e.g., Funk, supra note 159, at 1034 (noting a perceived "significant difference" between Chevron and Skidmore); Amy J. Wildermuth, Solving the Puzzle of Mead and Christensen: What Would Justice Stevens Do?, 74 FordHAM L. REV. 1877, 1890-99 (2006) (distinguishing between Chevron and Skidmore analysis); Eric R. Womack, Into the Third Era of Administrative Law: An Empirical Study of the Supreme Court's Retreat from Chevron Principles in United States v. Mead, 107 DiCK. L. REV. 289, 295 (2002) (referring to Chevron as a "dramatic shift" from Skidmore). But see Cass R. Sunstein, Chevron Step Zero, 92 VA. L. REV. 187, 226 (2006) (suggesting that there is often very little difference between Chevron and Skidmore deference); Russell L. Weaver, An APA Provision on Nonlegislative Rules?, 56 ADMIN. L. REV. 1179, 1186 (2004) (finding little difference between the standards). Professor Bressman believes that while application of the tests might result in similar outcomes in many cases, the choice of a standard is important because adoption of the Skidmore standard delegates greater interpretive authority to courts and reduces an agency's ability to change its policies over time. See Bressman, supra note 265, at 1466-68.

267. See Womack, supra note 266, at 295.

268. See id. at 327-28.

269. See Wildermuth, supra note 266, at 1898-99.

270. See David Zaring, Reasonable Agencies, 96 VA. L. REV. 135, 170-76 (2010).

271. Id. at 169-78.

272. Id. After reviewing twelve empirical studies, Zaring concludes that courts affirm agencies' decisions in sixty to seventy percent of the cases, regardless of which standard the Court applies. Id. at 169. Consequently, he advocates replacing all of the standards with a single "reasonableness" standard. Id. at 138-39.

273. Id. at 174-75 (citing Hickman \& Krueger, supra note 191, at 1235). Hickman and Krueger examined 106 opinions involving Skidmore review that the federal courts of appeals issued "in the 
Chevron case study cited by Zaring with the largest sample size was seventy-six percent, however, and several of the Chevron studies he reviewed found affirmance rates near seventy percent or higher. ${ }^{274}$ Thus, the studies he reviewed demonstrated a difference between the application of the Chevron and Skidmore standards in practice and would have demonstrated an even greater difference had he included the Womack and Wildermuth studies. Even Hickman and Krueger, the authors of the Skidmore study that he included, conclude that Skidmore affords agencies less deference than Chevron. ${ }^{275}$

Franklin further suggests that agencies receive a higher level of deference than Chevron when they adopt nonlegislative rules that interpret legislative rules. He is correct that under Auer v. Robbins, courts will defer to an agency's interpretation of its own regulations unless that interpretation is "plainly erroneous or inconsistent with the regulation." 276 This higher level of deference only applies when the nonlegislative rule interprets ambiguous language in a legislative rule, ${ }^{277}$ rather than a statute, and does not apply when the legislative rule merely parrots the language in the statute. ${ }^{278}$

More importantly, however, the prospect of Auer deference will not necessarily motivate agencies to announce policies and interpretations through nonlegislative rulemaking in a short cut regime because agencies can receive the same high level of deference for those interpretations even if they have not articulated them in a nonlegislative rule. The Supreme Court has stressed, in case after case, that Auer deference applies to an agency's interpretation of its legislative rule even if it raises it for the first time in an amicus brief or other legal pleadings. ${ }^{279}$ Indeed,

first five years of the modern Skidmore era.” Hickman \& Krueger, supra note 191, at 1267.

274. Zaring, supra note 270, at 171. Professor Peter Schuck and Elliott's 1990 review of appellate court Chevron opinions identified a seventy-seven percent validation rate for agencies' decisions. See Peter H. Schuck \& E. Donald Elliott, To the Chevron Station: An Empirical Study of Federal Administrative Law, 1990 DUKE L.J. 984, 1007-09 (1990).

275. See Hickman \& Krueger, supra note 191, at 1250. They stress, though, that the Skidmore standard is more deferential than suggested by the Womack and Wildermuth studies, and they criticize the small sample sizes — and some of the methodologies_of both studies. Id. at 1278-79.

276. 519 U.S. 452, 461 (1997) (quoting Robertson v. Methow Valley Citizens Council, 490 U.S. 332, 359 (1989)) (internal quotation marks omitted).

277. See Christensen v. Harris Cnty., 529 U.S. 576, 588 (2000) (finding that the regulatory language was not ambiguous, thus Auer did not apply).

278. See Gonzales v. Oregon, 546 U.S. 243, 257 (2006).

279. See, e.g., Talk Am. Inc. v. Mich. Bell Tel. Co., 131 S. Ct. 2254, 2261 (2011) (deferring to an agency’s interpretation unless "plainly erroneous" (quoting Chase Bank USA, N.A., v. McCoy, 131 S. Ct. 871, 880 (2011))); Chase Bank, 131 S. Ct. 880-81 (2010) (deferring to agency interpretation advanced in a legal brief); Kennedy v. Plan Adm'r for DuPont Sav. \& Inv. Plan, 555 
most of the Supreme Court cases involving Auer deference involve agencies advancing initial interpretations of regulations, rather than in nonlegislative rules. ${ }^{280}$ Incidentally, Franklin's concerns about Auer are misplaced because agencies would have the same incentive to advance their interpretations of legislative rules for the first time in court under a legal effects test regime as they would in a short cut regime.

\section{Responding to Professor Seidenfeld's Proposal}

Although Franklin's criticisms of the trade off associated with the short cut may be flawed, both he and Seidenfeld, among others, correctly assert that (1) nonlegislative rules generate less opportunity for public participation and (2) some nonlegislative rules will not face judicial review. ${ }^{281}$ While Franklin cites these shortcomings as reasons to abandon the short cut, ${ }^{282}$ Seidenfeld suggests reforms to address these issues by providing immediate substantive, rather than procedural, review of nonlegislative rules based on a heightened standard of review. $^{283}$

Seidenfeld's proposal to modify the doctrines of ripeness and finality, which would enable stakeholders to bring immediate substantive challenges to nonlegislative rules upon their adoption, ${ }^{284}$ likely significantly increases the agencies' cost of adopting nonlegislative rules. Agencies will need to draft nonlegislative rules in a way that anticipates, and can withstand, immediate facial challenges. Such drafting will necessarily consume more time and resources than the current process for developing nonlegislative rules. Seidenfeld recognizes that only narrow modifications to the ripeness and finality doctrines will avoid spurring a flood of lawsuits that would chill the use of nonlegislative rulemaking. ${ }^{285}$ Still, his proposal to allow suits whenever a rule is "pragmatically binding," rather than focusing on a limited universe of

U.S. 285, 295-96 (2009) (holding that an agency's interpretation of its own rule is “controlling”); Fed. Express Corp. v. Holowecki, 552 U.S. 389, 397 (2008) (noting the significant deference afforded agency interpretations under Auer); Riegel v. Medtronic, Inc., 552 U.S. 312, 328 (2008) (noting that an agency's interpretation of its own rule is entitled to substantial deference).

280. See sources cited supra note 279.

281. Franklin, supra note 5, at 304-05.

282. Id. at 303-07.

283. Seidenfeld, supra note 13, at 373-75.

284. See id.; supra text accompanying notes 213-14, 222-29.

285. See Seidenfeld, supra note 13, at 380-81; supra text accompanying notes 225-26. Seidenfeld defines "pragmatically binding" as "likely to affect" behavior of regulated entities. Seidenfeld, supra note 13, at 381. 
nonlegislative rules likely to have a significant impact, is too broad and is likely to encourage precisely the flood of lawsuits that he hopes to prevent. As previously noted, when faced with increased time and resource costs for developing and defending nonlegislative rules, agencies will likely choose to adopt policies through adjudication rather than legislative or nonlegislative rulemaking. That trend would not increase public participation in the development of the policies and interpretations, and it would give stakeholders less advance notice of the policies and interpretations. ${ }^{286}$ Even if the increased likelihood of litigation over nonlegislative rules did not encourage agencies to abandon nonlegislative rulemaking, it would surely slow the nonlegislative rulemaking process. Consequently, to the extent that agencies' policies and interpretations protect regulatory beneficiaries from health, environmental, economic, or other harms, time-consuming preparation for immediate facial challenges will delay those benefits.

More fundamentally, however, Seidenfeld's proposal to allow direct, immediate substantive review of nonlegislative rules $^{287}$ is misguided because it divorces the nonlegislative rule from the concrete situations in which the agency will ultimately apply it. Seidenfeld's approach treats the nonlegislative rule like a legislative rule and requires the agency to anticipate and justify all situations in which the agency may apply the rule. When an agency develops a nonlegislative rule, however, it generally leaves some questions about the rule unanswered, preferring to resolve them per its discretion when it applies the rule. When the agency applies its nonlegislative rule, it must justify its action as reasonable. The agency should not have to justify it in the abstract before it applies the rule. Seidenfeld's proposal requires just this.

Seidenfeld's proposal to impose a form of hard-look review on an agency's nonlegislative rules ${ }^{288}$ is misguided for similar reasons. Once again, Seidenfeld treats the nonlegislative rule like a legislative rule. He recognizes that his modified hard-look review will be difficult for courts to implement without a record of the agency's action to review, so he proposes, in essence, a record requirement for agencies' nonlegislative rules. ${ }^{289}$ If, on the other hand, courts waited to review nonlegislative rules until the agencies actually applied them, then courts would have a

286. See supra text accompanying notes 246-47.

287. See supra text accompanying notes 222-23.

288. See supra notes $230-39$ and accompanying text.

289. See supra note 232 and accompanying text. 
record of the agencies' decisions to review for reasonableness. Seidenfeld's proposal to require agencies to explain their nonlegislative rules upon adoption, in terms of all plausible factors and alternatives, is too costly and time consuming and will encourage agencies to abandon nonlegislative rulemaking. Agencies will likely need to be overly conservative in estimating what factors and alternatives courts will require them to consider.

\section{Is There Even a Problem?}

While Franklin and Seidenfeld, among others, raise legitimate concerns about decreased opportunities for public and judicial oversight of nonlegislative rulemaking, ${ }^{290}$ a recent empirical review of nonlegislative rulemaking suggests that agencies do not abuse the process, perhaps implying that reforms are unnecessary. ${ }^{291}$ Analyzing guidance documents issued by five federal agencies between 1996 and 2006, Connor Raso concluded that the agencies did not issue guidance documents strategically. ${ }^{292}$ Raso based his conclusion on several findings. First, Raso observed that the agencies he reviewed issued guidance documents less frequently towards the end of a presidential administration, whereas agencies acting strategically would likely increase their use of guidance at that time to quickly implement their policies before the change of administration. ${ }^{293}$ Second, Raso observed that the agencies he reviewed did not issue guidance documents significantly more frequently during times of divided government. ${ }^{294}$ Agencies acting strategically would likely increase their use of guidance

290. See, e.g., Franklin, supra note 5, at 324; Gersen, supra note 7, at 1720; Seidenfeld, supra note 13 , at 332-33.

291. Connor N. Raso, Note, Strategic or Sincere? Analyzing Agency Use of Guidance Documents, 119 YALE L.J. 782, 805-20 (2010).

292. Id. at 805, 821. Raso examined guidance documents issued by the Environmental Protection Agency, the Food and Drug Administration, the Federal Communications Commission, the Occupational Safety and Health Administration, and the Internal Revenue Service. Id. at 805.

293. Id. at 806. Raso is correct that it might be quicker and easier to implement a policy through a guidance document than through a legislative rule at the end of an administration, but agencies might have a greater incentive to adopt major policies and interpretations through legislative rulemaking than through guidance at the end of an administration because it would be more difficult for the incoming administration to change the policy if it were adopted as a legislative rule. For background on late-term administrative action, see Jack M. Beermann, Combating Midnight Regulation, 103 Nw. U. L. ReV. ColloquY 352 (2009); Jason M. Loring \& Liam R. Roth, Empirical Study, After Midnight: The Durability of the "Midnight" Regulations Passed by the Two Previous Outgoing Administrations, 40 WAKE FOREST L. REV. 1441 (2005).

294. Raso, supra note 291, at 807. 
documents under divided government. Guidance documents would attract less attention from both branches of government, and conflict with at least one branch of government over the agencies' policies would be more likely when political parties split control of the White House and Congress. ${ }^{295}$ Third, Raso observed that the agencies he reviewed did not issue more guidance documents when Congress increased oversight of the agencies, whereas agencies acting strategically would likely increase their use of guidance documents to avoid the procedural requirements of legislative rulemaking that might attract congressional interest. ${ }^{296}$ Finally, Raso observed that the agencies he reviewed did not increase their use of guidance documents when agencies faced increased judicial challenges to their actions, whereas agencies acting strategically would likely increase their use of guidance documents to reduce the potential for judicial challenges. ${ }^{297}$

In addition to concluding that agencies do not issue guidance documents strategically, Raso concluded that agencies did not systematically use nonlegislative rulemaking to avoid the legislativerulemaking process for significant policy decisions. ${ }^{298}$ He noted that the number of significant legislative rules adopted by agencies dwarfed the number of significant guidance documents issued by agencies. ${ }^{299}$ Finally, Raso concluded that the agencies did not use guidance documents to implement "ideologically charged policy decisions"300

295. Id.

296. Id. at 807-08. Raso, however, measures the number of agency-oversight hearings held by congressional committees and concludes that more hearings indicate congressional dissatisfaction with the agency. Id. at 808. Raso admits that using such hearings to measure congressional dissatisfaction with agencies is "imperfect" because congressional hearings may indicate a response to important external changes in an agency’s policy area and, more importantly, because the number of hearings could increase as a response to high profile rulemaking by the agency. Id.

297. Id. at 809-10. Raso found a "weakly negative" correlation between the number of lawsuits brought against an agency and its proportional use of guidance documents and suggested that “additional data would increase confidence in this conclusion.” Id. at 810.

298. Id. at 813-14.

299. Id. Raso defined "significant" guidance documents and "significant” rulemaking according to the definitions used by the OMB. Id. at 812 . Raso noted that 723 significant guidance documents were in effect at the time of his study, while OMB reviewed over 10,800 significant legislative rules between 1993 and 2008. Id. at 813. While Raso found that some agencies issued guidance documents at a significantly higher rate than others, he concluded that "the behavior appears to be motivated by the agency's need to fulfill a policy mandate within a time constraint," rather than constituting a pattern of strategic behavior by the agency. Id. at 814 . He also found that agencies used much of their guidance to clarify highly technical details and noted that "the technical nature of these regulations required frequent and rapid clarification, which was not amenable to the much slower rulemaking process.” $I d$. at 815.

300. Id. at 816. 
because a change in the presidential administration reversed very few of the guidance documents issued during the study period. ${ }^{301}$ Overall, he concluded that "the consternation over guidance documents raised in both the academic and policy realms is overstated." ${ }^{\text {302 }}$

\section{E. The Need for Reform}

While Raso may ultimately be correct that agencies do not systematically abuse nonlegislative rulemaking to avoid notice-andcomment procedures, agencies' appropriate use of nonlegislative rulemaking to address significant policy issues still raises concerns regarding lack of public and judicial oversight identified by Franklin, Seidenfeld, and others. ${ }^{303}$ The EPA's recent guidance defining "waters of the United States" is a good example of a significant policy decision arising through nonlegislative rulemaking, ${ }^{304}$ though the agency has taken several steps with that guidance to facilitate public participation. ${ }^{305}$ The agency's guidance regarding permitting for greenhouse gases is another example. $^{306}$ In both cases, the guidance addresses a highly technical area in which the agency continually gathers information before making a final decision regarding the application of environmental statutes to specific facts, but some immediate action is necessary to address a pressing environmental problem. Legislative rulemaking would be a poor policy choice for addressing those problems

301. Id. at 816-18. Raso found that agencies modified guidance documents less frequently than legislative rules. $I d$. at 818 .

302. Id. at 821. Raso suggests that the consternation might arise from (1) "overgeneralization from a few egregious examples of abuse"; (2) "interest groups seeking to reduce regulation by consuming limited agency resources with additional procedural requirements"; or (3) "fear among congressional staffers and OMB officials that agencies are subverting their authority." Id.

303. See supra sources cited note 290.

304. See EPA and Army Corps of Engineers Guidance Regarding Identification of Waters Protected by the Clean Water Act, 76 Fed. Reg. 24,479 (May 2, 2011).

305. The EPA issued the guidance in draft form on May 2, 2011 and accepted public comment on it until July 1, 2011. Id. at 24, 479. On its website, the EPA posted the full docket containing the draft guidance, prior guidance, supporting material for the guidance, and all public comments. Id. at 24, 480. In addition, the EPA solicited public participation through Facebook, Twitter, and a blog. See Clean Water Act Definition of "Waters of the United States", U.S. ENVTL. Protection AGENCY, http://water.epa.gov/lawsregs/guidance/wetlands/CWAwaters.cfm (last visited Nov. 8, 2011). Further, the agency indicates that it plans to propose revisions to its regulations regarding "waters of the United States" that will supersede the guidance. EPA and Army Corps of Engineers Guidance Regarding Identification of Waters Protected by the Clean Water Act, 76 Fed. Reg. at 24,479 .

306. PSD and Title V Permitting Guidance for Greenhouse Gases, 75 Fed. Reg. 70,254 (Nov. 17, 2010). 
in the short term. Although the agency is not strategically avoiding notice-and-comment rulemaking in these instances, the concerns regarding lack of public and judicial oversight identified by Seidenfeld, Franklin, and others ${ }^{307}$ could easily surface if the agency adopted the guidance without providing any opportunity for public input.

Accordingly, Seidenfeld and others correctly note that some changes could allow opportunities for public participation and judicial review of nonlegislative rules if courts adopt the short cut. ${ }^{308}$ They also correctly argue, however, that the changes should not impose extensive procedural requirements on agencies or significantly expand judicial review to a degree that discourages the use of nonlegislative rulemaking. ${ }^{309}$

\section{F. An Alternative Reform Proposal}

Perhaps the best way to balance these competing objectives would arise through legislation that provides increased opportunities for both (1) judicial review of guidance documents that might otherwise be unreviewable, such as deregulatory policies or nonenforcement policies, and (2) public participation when agencies adopt significant guidance documents. The OMB's Bulletin for Agency Good Guidance Practices embodies a good example. ${ }^{310}$ The OMB Bulletin requires agencies to post significant guidance documents on the Internet and provide notice and opportunity for public comment on those documents. ${ }^{311}$ The legislation might even require agencies to submit a notice to each house

\footnotetext{
307. See supra sources cited note 290.

308. See Seidenfeld, supra note 13, at 364 .

309. See id. at 373-75.

310. See infra Part V.G.1. In an earlier article, I proposed a more general amendment to the APA that would require agencies " 'to the extent practicable, necessary and in the public interest' to 'provide opportunities for timely and meaningful public participation'” when adopting guidance documents. Johnson, supra note 3, at 697. I further proposed an amendment to the judicial review provisions of the APA to provide for a sliding scale of deference for agency guidance documents, with courts according agency guidance greater deference when the agency uses notice-and-comment procedures. See id. On further reflection, that proposal would probably be difficult for courts to administer because it provides substantial discretion for agencies to determine what procedures to use when developing guidance. At the same time, while the article proposed according agencies greater deference when adopting rules using notice-and-comment procedures, that proposal would set Skidmore deference as the highest level of deference available to agencies. See id. Thus, the proposal in the article would not provide a significant incentive to agencies to use notice-andcomment procedures, since they should receive Skidmore deference without using those procedures under existing precedent without any reforms. By contrast, the proposal in this Article mandates a specific type of public participation for significant guidance documents.

311. See Final Bulletin for Agency Good Guidance Practices, 72 Fed. Reg. 3432, 3440 (Jan. 25,
} 2007). 
of Congress when adopting significant guidance. ${ }^{312}$ To avoid confusion regarding application of the short cut, the proposal should require agencies to identify interpretive rules and general statements of policy as such at the time of adoption, as proposed by Administrative Conference of the United States (ACUS), Funk, and others. ${ }^{313}$ My proposal would not, however, increase opportunities for judicial review of guidance documents that "coerce" compliance or change the standard of review for guidance documents, as Seidenfeld proposes.

The proposal has several advantages. First, although it expands agencies' obligations to solicit public input on nonlegislative rules, it is a modest expansion because it applies narrowly to significant guidance documents. Critics of nonlegislative rulemaking generally have not advocated for full notice-and-comment procedures for all nonlegislative rules. ${ }^{314}$ Instead, concern focuses on agencies' abuse of nonlegislative rulemaking to avoid notice-and-comment procedures for important policies and interpretations. Thus, there is no need to extend publicparticipation reforms beyond significant guidance documents. When ACUS suggested reforms to the nonlegislative-rulemaking process in 1976, it similarly limited its call for increased public notice-and-

312. The proposal would simply require that the agency send notice to Congress and would neither delay the implementation of the guidance nor provide for any streamlined congressional procedures to disapprove of the guidance, such as those established by the Congressional Review Act of 1996 for major legislative rules. See 5 U.S.C. $\S \S 801,802$ (2006). The Congressional Review Act defines a "major rule" as a rule that has resulted in, or will likely result in, an annual effect on the economy of $\$ 100$ million or more, a large increase in costs or prices for consumers, industries, or state and local governments, or significant adverse effects on the economy. Id. $\S 804(2)$. Even if the proposal modeled congressional notice on the Congressional Review Act, it is not clear that such legislation would significantly interfere with agencies' adoption of nonlegislative rules. Between the time that Congress enacted the Congressional Review Act in 1996 and May 2008, over 47,540 major and non-major rules were reported to Congress under the Act, and only one rule has been disapproved. MORTOn Rosenberg, CONG. RESEArCH SERV., CONGREsSiOnAL REVIEW OF AGENCY RULEMAKING: AN UPDATE AND ASSESSMENT OF THE CONGRESSIONAL REVIEW ACT AFTER A DECADE 1 (2006). In fact, only forty-seven joint resolutions of disapproval were even introduced over that time period. Id. Further, a Congressional Research Service report suggests that the Congressional Review Act already applies to interpretive rules and policies, although agencies have not been sending reports to Congress on those nonlegislative rules. Id. at 2-3.

313. See Johnson, supra note 3, at 739-40. Without such clarification, if an agency adopted an economically significant guidance document through notice-and-comment proceedings-as contemplated by the OMB Bulletin and by this proposal-without identifying the guidance as guidance, there could be some confusion regarding whether the document was a nonbinding guidance document or a binding legislative rule.

314. Professor Robert Anthony has argued that an agency should adopt all significant policies through notice-and-comment rulemaking. See Robert A. Anthony, Interpretive Rules, Policy Statements, Guidances, Manuals, and the Like-Should Federal Agencies Use Them to Bind the Public?, 41 DuKE L.J. 1311, 1314-16 (1992) (recommending that any legislative changes be announced to the public). 
participation procedures to guidance documents having a "substantial impact." ${ }^{315}$ While my proposal will raise the cost of adopting significant guidance documents, it likely will not drive agencies toward adopting those policies and interpretations through adjudication or simply withholding disclosure of those positions. As Mendelson notes, agencies may continue to adopt significant policies and interpretations through nonlegislative rulemaking despite the additional costs because they wish to treat regulated entities fairly, or appear to treat them fairly, and because they wish to maintain good relations with regulated entities in order to encourage compliance with the law and facilitate access to information from those entities that the agencies need to administer the law. ${ }^{316}$ Agencies may wish to provide advance notice because it allows the agency to obtain penalties against regulated entities in court for statutory or regulatory violations. ${ }^{317}$

A second advantage of the proposal is that it does not impose substantial additional procedural requirements on agencies beyond those that currently apply to nonlegislative rulemaking. Although Executive Order $13,422,{ }^{318}$ which motivated the OMB to adopt its Bulletin, has been revoked, ${ }^{319}$ the OMB Bulletin is still effective, and agencies have complied with the procedures required by it for four years. ${ }^{320}$ Contrary to my early skepticism, ${ }^{321}$ the procedures required by the OMB Bulletin have neither significantly ossified the nonlegislative-rulemaking process nor encouraged agencies to abandon nonlegislative rulemaking. In addition, Congress has previously imposed similar public-participation

315. Interpretive Rules of General Applicability and Statements of General Policy (Recommendation No. 76-5), 1 C.F.R. §305.76-5 (1993). Initial publication of the recommendations occurred in 1976. See Recommendations of the Administrative Conference of the United States, 41 Fed. Reg. 56,767, 56,769 (Dec. 30, 1976) (to be codified at 1 C.F.R. pt. 305).

316. Mendelson, supra note 42, at 435.

317. Id. at 436 .

318. 72 Fed. Reg. 2763 (Jan. 18, 2007). Executive Order 13,422 required agencies to submit "significant" guidance documents to OMB for review before agencies adopted the guidance. See id. at 2764-65.

319. Exec. Order No. 13,497, 74 Fed. Reg. 6113 (Jan. 30, 2009).

320. See Final Bulletin for Agency Good Guidance Practices, 72 Fed. Reg. 3432, 3432-33 (Jan. 25 , 2007). As required by the OMB Bulletin, agencies have adopted good guidance procedures and routinely post significant guidance documents on the Internet. See, e.g., Significant Guidance Documents, U.S. ENVTL. PROT. AGENCY, http://www.epa.gov/lawsregs/policy/sgd/ (last visited Nov. 8, 2011); OSHA Significant Guidance Documents Subject to EO 12,866 and OMB's Bulletin for Agency Good Guidance Practices, U.S. DEP'T OF LABOR, http://www.osha.gov/guidancedocuments.html (last visited Nov. 8, 2011); Significant Guidance Documents, U.S. DEP’T OF EDUC., http://www.ed.gov/policy/gen/guid/significant-guidance.html (last visited Nov. 8, 2011).

321. See Johnson, supra note 3, at 696-97 (arguing that the OMB Bulletin would ossify the rulemaking process and encourage agencies to abandon nonlegislative rulemaking). 
requirements on the Food and Drug Administration, and that law has not prevented the agency from adopting important policies and interpretations through nonlegislative rulemaking. ${ }^{322}$

A third advantage of the proposal is that it is consistent with President Obama's initiatives to encourage e-rulemaking and increase transparency and public participation in government. ${ }^{323}$ Similarly, it is consistent with President Obama's Executive Order 13,563, which provides that the regulatory system "must allow for public participation and an open exchange of ideas. It must promote predictability and reduce uncertainty.... It must ensure that regulations are accessible, consistent, written in plain language, and easy to understand." 324 Public participation in the notice-and-comment process endures frequent criticism on the grounds that the opportunity for comment comes too late, at a time when the agency has devoted substantial time and resources to developing a proposed rule and is likely reluctant to significantly modify its proposed rule. ${ }^{325}$ The proposal to expand public participation in the development of significant guidance documents provides the public with an opportunity to influence an agency before the agency gets to the notice-and-comment stage. The process that the EPA

322. See 21 U.S.C. § 371(h)(1) (2006). This required the FDA to establish a set of policies and procedures entitled "Good Guidance Practices," id. § 371(h)(5), which the agency adopted in 2000. 21 C.F.R. § 10.115 (2006). Pursuant to those practices, the FDA has committed to full notice-andcomment procedures for "Level 1 guidance documents.” Id. § 10.115(g)(1)(ii) (2006). Level 1 guidance documents "(i) [s]et forth initial interpretations of statutory or regulatory requirements; (ii) [s]et forth changes in interpretation or policy that are of more than a minor nature; (iii) [i]nclude complex scientific issues; or (iv) [c]over highly controversial issues.” Id. §10.115(c)(1). For guidance documents that are not Level 1, the FDA posts the guidance documents on the Internet and gives the public an opportunity to comment, but the FDA does not need to reply to those comments. Id. § 10.115(g)(4).

323. Immediately upon taking office, President Obama issued a memorandum to federal executive agencies requiring them to use the latest available technologies to increase transparency, participation, and collaboration in decision-making. See Transparency and Open Government, 74 Fed. Reg. 4685 (Jan. 21, 2009). E-rulemaking is also central to the President's plan for open government. See, e.g., OfFice Of Mgmt. \& BUdget, Open Government Plan 1 (2010), available at http://www.whitehouse.gov/sites/default/files/microsites/100407-omb-opengov-plan.pdf; see also John Moses, Improving Online Public Participation in Agency Rulemaking, OpEN GOVERNMENT INITIATIVE (June 12, 2009, 5:03 PM), http://www.whitehouse.gov/blog/Improving-Online-PublicParticipation-in-Agency-Rulemaking. For a brief history of federal e-rulemaking efforts, see Cynthia R. Farina et al., Rulemaking 2.0, 65 U. MiAmI L. REv. 395 (2011).

324. Exec. Order No. 13,563, 76 Fed. Reg. 3821, 3821 (Jan. 18, 2011). Although much of the order focuses on legislative rules, the principles in the order apply to the regulatory process in general. See id. 3821-23.

325. See, e.g., Dorit Rubinstein Reiss, Tailored Participation: Modernizing the APA Rulemaking Procedures, 12 N.Y.U. J. Legis. \& PUB. POL'Y 321, 331-35 (2009); Stephanie Stern, Cognitive Consistency: Theory Maintenance and Administrative Rulemaking, 63 U. PITT. L. REV. 589, 621-22 (2002). 
used to define "waters of the United States" under the Clean Water Act could be a model for a more inclusive nonlegislative-rulemaking process, where an agency proposes guidance, seeks public input on the guidance, and modifies and applies the guidance in light of that input before moving on to notice-and-comment rulemaking. ${ }^{326}$ Such an elaborate process should not become the norm for nonlegislative rulemaking. Still, it seems particularly appropriate where the agency lacks sufficient information or experience to set forth a binding policy or interpretation at the outset. It may also be appropriate where the agency, for political reasons, wishes to provide additional opportunities for public participation in the development of the regulation or wishes to delay ultimate adoption of the legislative rule until political winds shift.

A final advantage of the proposal is that it facilitates congressional action if Congress disapproves of an agency's use of nonlegislative rulemaking. Agencies will post significant nonlegislative rules, along with public comments on the rules, on the Internet so Congress will have notice of the adoption of significant nonlegislative rules. Legislators will know what policies and interpretations agencies adopt through nonlegislative rulemaking as well as the concerns raised by their constituents with regard to those rules. If Congress determines that an agency should use notice-and-comment rulemaking to adopt the policy or interpretation in question, then it can require it through legislation. When Congress mandates the use of legislative rulemaking, courts will no longer defer to an agency's choice of an alternative policymaking tool under Chenery II. ${ }^{327}$

\section{G. The Proposal in Detail}

\section{Public Participation}

To respond to concerns that nonlegislative rules provide insufficient opportunities for public participation, Congress could adopt legislation similar to the Clearing Unnecessary Regulatory Burdens Act (CURB Act), proposed by Senator Susan Collins, which basically adopts the procedures of the OMB Bulletin as law. ${ }^{328}$ Specifically, legislation would require agencies to develop procedures for the approval of

326. See supra notes 304-05 and accompanying text.

327. SEC v. Chenery Corp., 332 U.S. 194, 208-09 (1947).

328. Clearing Unnecessary Regulatory Burdens Act (CURB Act), S. 602, 112th Cong. (2011). 
significant guidance documents, as defined in the OMB Bulletin ${ }^{329}$ including requirements that the appropriate senior officials approve the document and label it as guidance-and would require agencies to maintain a list of significant guidance documents on their website. ${ }^{330}$ The legislation would require streamlined public participation for significant guidance documents. Specifically, as in the CURB Act and the OMB Bulletin, the legislation would require agencies to provide public notice when they adopt significant guidance documents. ${ }^{331}$ Further, it would require agencies to provide the public with an opportunity to electronically submit comments on the guidance, but it would not require the agency to provide that opportunity before adopting the guidance and would not require the agency to specifically respond to comments. ${ }^{332}$ There would not be a specific time limit on the submission of comments, so the public could continue to submit comments as the agency applied the guidance over time. ${ }^{333}$ Unlike the CURB Act, the legislation might also require agencies to notify each house of Congress when they adopt a significant guidance document. ${ }^{334}$ Finally, for a more limited universe of significant guidance documents that qualify as "economically significant" as defined in the OMB Bulletin, ${ }^{335}$ the

329. A “significant guidance document” according to the OMB Bulletin, is one that may reasonably be anticipated to: (i) Lead to an annual effect on the economy of $\$ 100$ million or more or adversely affect in a material way the economy, a sector of the economy, productivity, competition, jobs, the environment, public health or safety, or State, local, or tribal governments or communities; (ii) Create a serious inconsistency or otherwise interfere with an action taken or planned by another agency; or (iii) Materially alter the budgetary impact of entitlements, grants, user fees, or loan programs or the rights and obligations of recipients thereof; or (iv) Raise novel legal or policy issues . . . .

Final Bulletin for Agency Good Guidance Practices, 72 Fed. Reg. 3432, 3434 (Jan. 25, 2007).

330. Compare id. at 3437 (requiring agencies to allow the pubic access to all significant guidance documents via the agencies' websites) with CURB Act, S. 602 § 2(c) (requiring both approval by appropriate senior agency officials and maintenance of a website to allow the public access to the text of significant guidance documents). In 1992, ACUS recommended that agencies label interpretive rules and general statements of policy as such when they adopted them to avoid any confusion regarding the nature of the rules. See Agency Policy Statements (Recommendation No. 92-2), 1 C.F.R. § 305.92-2 (1993).

331. See CURB Act, S. 602 § 2(c); Final Bulletin for Agency Good Guidance Practices, 72 Fed. Reg. at 3437-38.

332. See CURB Act, S. 602 § 2(c); Final Bulletin for Agency Good Guidance Practices, 72 Fed. Reg. at 3437-38.

333. See CURB Act, S. 602 § 2(c); Final Bulletin for Agency Good Guidance Practices, 72 Fed. Reg. at 3437-38.

334. See supra note 312 and accompanying text.

335. The OMB Bulletin defines an "economically significant guidance document" as one that “'may reasonably be anticipated to lead to’ an annual effect on the economy of \$100 million or more or adversely affect in a material way the economy or a sector of the economy.” Final Bulletin for 
legislation could require the agency to utilize traditional notice-andcomment procedures, including providing the public with an opportunity to comment before the agency adopts the guidance and imposing on the agency an obligation to respond to comments. ${ }^{336}$

This Article outlines advantages of the proposal above. The proposal focuses on the types of guidance documents where abuse of the noticeand-comment system would be most troubling and formalizes an administrative procedure that has been implemented for several years without significantly chilling the appropriate use of nonlegislative rulemaking. It expands public participation opportunities but does not impose a requirement on agencies to use of full-blown notice-andcomment procedures except in very limited circumstances. ${ }^{337}$ In most cases, therefore, the agency can implement the guidance documents while reviewing public comments over time.

One should expect some criticism of the proposal, however. For instance, Mendelson has criticized the approach taken in the OMB Bulletin because, she asserts, agencies will not meaningfully engage or review the comments they receive on guidance documents unless the law obligates them to respond. ${ }^{338}$ Although she believes that comments from entities with significant political clout will receive attention, she does not believe that agencies will address concerns raised by regulatory beneficiaries in general. ${ }^{339}$ Mendelson argues that agencies that fail to respond to comments under the OMB Bulletin are only accountable to

Agency Good Guidance Practices, 72 Fed. Reg. at 3435.

336. See CURB Act, S. 602 § 2(c)(3); Final Bulletin for Agency Good Guidance Practices, 72 Fed. Reg. at 3440 .

337. Agencies seem to interpret "economically significant guidance document" very narrowly. A search of the Federal Register in LexisNexis did not identify any cases where an agency requested notice and comment on an economically significant guidance document since the OMB Bulletin went into effect. This was determined by logging in to the Federal Register database and performing a search with the following search strings: (1) "economically significant /p bulletin and guidance"; and (2) "economically significant /p good guidance." Similarly, a search of OMB's reginfo.gov website did not identify any OMB reviews of economically significant guidance documents while Executive Order 13,422 was in effect. See Historical Reports, Office OF MGMT. \& BudgET, http://www.reginfo.gov/public/do/eoHistoricReport (last visited Nov. 8, 2011).

338. See Mendelson, supra note 42 , at 448.

339. Id. While the OMB Bulletin requires full notice and comment for "economically significant” guidance documents, Mendelson argues that there are very few guidance documents that would be "economically significant" and that those guidance documents, while important to regulated entities, would not be the documents that concern regulatory beneficiaries most. Id. at 449. Regulatory beneficiaries would be most concerned with guidance documents that reduce economic burdens on regulated entities by reducing regulatory compliance burdens, and those documents would not likely be "economically significant." Id. 
OMB, as the Bulletin does "not create rights enforceable in court."340 Legislation, however, could create rights enforceable in court. More importantly, agencies could never simply ignore comments that they received on guidance documents, even if they had no obligation to respond to the comments. When the agency ultimately implements a policy or interpretation adopted in a nonlegislative rule in a concrete factual setting, it must justify its decision as reasonable if challenged in court. If an agency's decision is unreasonable when viewed in light of the comments received by the agency on its nonlegislative rule, then the court could strike down the agency's decision. The agency's obligation to act reasonably is independent of any procedural obligation to respond to comments.

Critics might also assert that a proposal to require enhanced public participation for "significant" nonlegislative rules might be difficult to implement because it is difficult to determine what guidance is "significant" enough to trigger enhanced participation. Mendelson, for instance, criticized Professor Robert Anthony's proposal to require notice-and-comment rulemaking for every significant aspect of an agency's policies on the grounds that the proposals would place significant demands on courts to determine which policy decisions of agencies were "significant" or "important." this Article, however, avoids that problem by providing concrete standards for courts to use to determine which agency decisions are "significant” or "economically significant."

\section{Judicial Review}

The legislative proposal could authorize judicial review of nonlegislative rules that adopt deregulatory or nonenforcement policies and that, therefore, would not otherwise face review in court. ${ }^{343}$ This

340. Id. at 449 (citing Memorandum from Rob Portman, Dir., Office of Mgmt. \& Budget, to Heads of Exec. Dep'ts and Agencies 18, available at http://www.whitehouse.gov/sites/default/files/ omb/memoranda/fy2007/m07-07.pdf).

341. Id. at 437-38, 444-45.

342. See supra notes 329,335 and accompanying text.

343. Professor Franklin described a variety of types of nonlegislative rules that fit this mold, including rules that set minimum criteria that trigger enforcement, rules that outline safe harbors for compliance, and rules that outline a general deregulatory policy or interpretation. See Franklin, supra note 5, at 309-10 (citing Anthony, supra note 314, at 1361). Although I suggested, in a prior article, that it was not necessary to institute any reforms to expand opportunities for judicial review of nonlegislative rules, see Johnson, supra note 3, at 733-34, because aggrieved parties could challenge the rule's ultimate application, Professors Franklin and Seidenfeld raise compelling 
proposal would benefit regulatory beneficiaries more than regulated entities because regulatory beneficiaries are more likely than regulated entities to be negatively impacted by the inability to challenge those types of decisions. Regarding "coerced compliance," it does not seem to be appropriate to change the doctrines of ripeness and finality to expand opportunities for judicial review in those cases, as Seidenfeld advocates. If an agency's nonlegislative rule has a sufficiently direct and immediate impact on a stakeholder's day-to-day business that it affects their rights or obligations, the stakeholder should be able to challenge it as a "final agency action." If the rule does not have that effect, then expanding judicial review to address those cases could significantly increase the cost to agencies of using nonlegislative rulemaking and discourage its use. Regarding ripeness, if a party cannot challenge an agency's nonlegislative rule because it is not clear how the agency will apply the rule in practice, then that will often be precisely the reason why the agency adopted its policy or interpretation as a nonlegislative rule, rather than a legislative rule. This is an appropriate reason to engage in nonlegislative rulemaking. Providing for immediate judicial review in such cases would frustrate the purpose of using nonlegislative rulemaking and encourage agencies to develop those policies or interpretations through adjudication.

Mendelson's proposal to expand judicial review of agencies' nonlegislative rules by creating a process to petition agencies to modify or repeal guidance documents could similarly increase the cost of nonlegislative rulemaking. ${ }^{344}$ Indeed, she recognizes this. ${ }^{345}$ Since her

arguments that these nonenforcement and deregulatory decisions may never face judicial review. See supra Parts III-IV.

344. Mendelson, supra note 42, at 441.

345. Id. Mendelson recognizes that the costs are lower than those imposed by requiring agencies to use notice-and-comment rulemaking for all guidance documents, that petitions would not be filed for the majority of agency guidance documents, which are generally uncontroversial, and that an attorneys' fee provision could further limit spurious petitions. Id. at 441-42. She acknowledges, however, that at some point, the costs associated with her proposal could discourage agencies from appropriately engaging in nonlegislative rulemaking. Id. at 442. Professor Seidenfeld, however, disagrees and suggests that Mendelson's proposal would not impose significant costs because stakeholders can already petition agencies to revise or repeal nonlegislative rules under the 5 U.S.C. §553(e), and that few have done so. See Seidenfeld, supra note 13, at 369-72. Although Mendelson argues that $\S 553(\mathrm{e})$ does not apply to nonlegislative rules, see Mendelson, supra note 42, at 439-40, Seidenfeld disagrees. See Seidenfeld, supra note 13, at 369-72. Mendelson is not alone in supporting a petition process for nonlegislative rules. The OMB Bulletin requires agencies to establish and clearly advertise on their websites a means for the public to petition the agency to issue, reconsider, modify, or rescind significant guidance documents, see Final Bulletin for Agency Good Guidance Practices, 72 Fed. Reg. 3432, 3440 (Jan. 25, 2007), but few agencies’ websites include such information. The proposed CURB Act also would require agencies to establish and 
proposal primarily intends to increase opportunities for judicial review by regulatory beneficiaries, the proposal in this Article to authorize judicial review of deregulatory and nonenforcement policies could provide some relief for regulatory beneficiaries at a lower cost for agencies. ${ }^{346}$

Finally, the modification of the standard of review for nonlegislative rules is not necessary. The costs associated with Seidenfeld's proposal could discourage agencies from appropriately using nonlegislative rulemaking. Agencies will likely need to be overly conservative in anticipating the factors and alternatives that courts will deem to be plausible and explain their rules in light of those factors and alternatives. $^{347}$ When an agency adopts a policy or interpretation through nonlegislative rulemaking, it sacrifices the binding effect and Chevron deference that comes with legislative rulemaking, but the agency maintains the flexibility to modify the policy or interpretation over time as it applies it to specific facts and receives input from stakeholders. Seidenfeld's proposal denies agencies that flexibility and requires agencies to develop a "record" for nonlegislative rulemaking. ${ }^{348}$ The proposal in this Article, by contract, requires agencies to justify the policy or interpretation in a nonlegislative rule when the agency applies it, based on the specific case and all information the agency has gathered from public comments and the application of the rule in other contexts. While a court will still review the agency's decision under Skidmore, the agency cannot ignore the public input that it has gathered on the rule over time because the Skidmore factors include consideration of both the validity of the agency's reasoning and the thoroughness evident in the agency's consideration. $^{349}$ Thus, the proposal expands opportunities for public participation in the development of nonlegislative rules without

clearly advertise on their website "a request for issuance, reconsideration, modification, or rescission of significant guidance documents," see CURB Act, S. 602 §2(c)(2)(B)(i)(II), but the legislation would not require agencies to formally respond to such requests. Id. § 2(c)(2)(B)(ii). Further, in 1992, ACUS recommended that agencies should "establish informal and flexible procedures that allow an opportunity to challenge policy statements." See Agency Policy Statements (Recommendation No. 92-2), 1 C.F.R. § 305.92-2 (1993).

346. Mendelson argues that a petition process would benefit regulatory beneficiaries by encouraging agencies to "consider a wider range of views before issuing guidances." See Mendelson, supra note 42, at 442. Expanding opportunities for judicial review to include nonenforcement and deregulatory decisions by agencies will achieve similar results for an important category of agencies' rules at a lower cost.

347. See supra Part V.C.

348. See supra notes 231-35 and accompanying text.

349. Skidmore v. Swift \& Co., 323 U.S. 134, 140 (1944). 
imposing sufficient costs on agencies to discourage the use of nonlegislative rulemaking.

\section{CONCLUSION}

The time has come for courts to discard the D.C. Circuit's unworkable legal effects test. Further, when Congress does not limit an agency's choice of policymaking tool, the agency should have the discretion to adopt a policy or interpretation through nonlegislative rulemaking and justify the policy or interpretation when it applies the rule, while avoiding spurious premature procedural challenges. To make the adoption of the short cut more palatable to critics who argue that it limits public and judicial oversight of nonlegislative rulemaking, this Article outlines a proposal that increases public participation in the development of "significant" nonlegislative rules and increases opportunities for judicial review of nonenforcement and deregulatory rules that might otherwise escape review. The proposal addresses the concerns regarding lack of oversight of nonlegislative rules, and it does not impose substantial additional costs on the nonlegislative-rulemaking process that could otherwise discourage agencies from using nonlegislative rulemaking when appropriate. Without rejection of the legal effects test and other reforms, agencies will face increasing pressure to adopt new policies and interpretations through adjudication. With reforms, agencies will have greater incentives to provide advance notice to the public about those policies and interpretations through nonlegislative rulemaking and gather valuable input from stakeholders in the development of those policies and interpretations. 